\title{
Henryk Grossman, a Marxist activist and theorist: on the 50th anniversary of his death
}

\author{
Rick Kuhn
}

\begin{abstract}
Some of Henryk Grossman's contributions to Marxist economic theory are familiar. Ignorance and misinformation about his life has accompanied and sometimes underpinned widespread criticism of his account of economic crises and neglect of his other work. Grossman's life and work before he moved to Frankfurt am Main in 1925 and wrote his best known publications are therefore outlined, highlighting his deep and active involvement in the Jewish social democratic movement in Galicia before and in the Polish Communist movement after the First World War.
\end{abstract}

Henryk Grossman, ${ }^{1}$ is best known as a Marxist economist and particularly for his substantial 1929 study, The Law of Accumulation and Collapse of the Capitalist System (Being also a Theory of Crises) (Grossmann 1929a, 1992). ${ }^{2}$ In this book and in four articles published between 1928 and 1932, when he was a member of the Institute for Social Research in Frankfurt am Main, he elaborated original arguments about Marx's method in Capital and the theory of economic crisis which are still reference points in the Marxist literature (Grossmann 1928, 1929b, 1932a, 1932b). There is also a broad awareness of his later published work in economics, the history of economic thought and on the origins of the scientific world view. Fifty years after his death on November 24, 1950, however, information about Grossman's life is still hard to come by.

The standard biographical sketches of Grossman's life, by Walter Braeuer (1954 and 1966) and K. H. Hennings (1970), focus on the economic studies he produced while associated with the Institute, in Frankfurt and New York. They fail to mention his involvement in the socialist movement in Galicia before the First World War and Warsaw during the early 1920s. Hennings assumes Grossman became a socialist during or immediately after the War. Martin Jay (1973 pp. 16-17), in his study of the Frankfurt School, does state that Grossman was a member of the Polish Communist Party, while Ulrike Migdal (1981 pp. 98, 127), in her account of the Institute's early history, refers to his 'apparently transitory membership', on the authority of Karl Wittfogel. Neither is aware of his earlier political engagement. Russell Jacoby (1975 p. 52) refers to 'Grossman's first Marxist writings' as appearing in 1924, almost two decades after the correct date. Most other English and German publications that deal with Grossman the economist draw on the work of these writers for biographical details. Perry Anderson (1976 p. 22 also Howard and King 1989 p. 317), for example, asserts that although the same age as Otto Bauer and older

This is a modified version of an essay originally published in Paul Zarembka (ed.) Value, capitalist dynamics and money, Research in political economy 18 2000, Elsevier Science, Amsterdam 2000 pp. 111-162. RPE web sites: http://ourworld.compuserve.com/homepages/PZarembka/homepage.htm,

www.elsevier.com/wps/find/bookseriesdescription.cws_home/BS_RPE/description

1 In Poland he was 'Henryk Grossman'. Henryk Grossmann' was the most common German rendition of his name and the one used in most of his own publications, but 'Henryk Großmann', 'Heinrich Großmann' and 'Heinrich Grossmann' also occur. The work whose appearance in English he oversaw himself are published under the name 'Henryk Grossman'. In what follows the name under which each publication originally appeared is used.

2 The English translation (Grossmann 1992) is abbreviated and lacks the concluding section of the book. Lapides (1994) proves a translation of part of this section. 
than Nikolai Bukharin, 'Grossman, however, had developed more slowly'. Ernst Glaser (1981 p. 236) does mention a pamphlet on the Jewish Question Grossman published in Polish in 1905, but not that it was the product of a deep involvement in the Galician labour movement. This involvement, however, was a crucial element in Grossman's political formation and had implications for his later, better known work. There is a separate historical literature, dealing with Austrian and Polish socialism, the Bund and the Jewish Question, which touches on Grossman's early political activity (Kisman 1966; Piasecki 1982; Najdus 1983; Wistrich 1981; Jacobs 1994; Löw 1984). In a Polish biographical dictionary, Ludwig Hass (1992) does provide a brief sketch of Grossman's activity in Galicia and his work as an economic theorist (also Kowalik 1960 and Scheele 1990).

The significance of Grossman's biography for his writings after 1927 was only initiated in an overview of his contributions to Marxist economics in 1995 (Kuhn 1995). Yet this background is of considerable importance. Grossman was very far from being a latecomer to Marxism preoccupied with dry points of doctrine. He became active in socialist politics at school, was for years a Marxist militant and identified passionately and for decades with workers in struggle. These experiences and commitments were at the core of his writings in Frankfurt.

The following outline draws on both secondary treatments of the eastern European labour movement and the Jewish Question and primary sources to fill in the largest gap in knowledge amongst political economists about Henryk Grossman's life: his political experiences and writing in Galicia and Vienna before and during the First World War and, from 1919, in independent Poland. A detailed consideration of the period after 1925, including the systematic discussion of his better known publications, as well as a thorough treatment of this earlier period, are part of a more comprehensive biographical study now in preparation.

\section{Marxist politics in Galicia}

Grossman was born in Kraków, the capital of western Galicia, on 14 April 1881. A little background about the city and the province is necessary before we explore his early social and political experiences.

Galicia was the Austrian section of partitioned Poland, which had ceased to exist as an independent state in 1795, and was economically backward by the standards of the Polish provinces of Russia and Germany and also the industrialized provinces of the Austro-Hungarian Empire, notably the Austrian crown lands and Bohemia and Moravia. ${ }^{3}$ In 1900 the population of Galicia was 7316 000. In the capital, Lemberg (Lwów in Polish, now Lviv in the Ukraine), situated in the east of the province, there were 159000 people. Eighty percent of Galicia's population lived on the land, three quarters of the workforce was engaged in agriculture. Towards the end of the 19th Century, the pace of industrial development quickened, but by 1900 there were only 77000 workers in industry and craft production in the province. Kraków was the second largest city with a population of 91800 .

Even in the modern sector of the economy, working conditions were very poor by western European standards. In 1900 miners, printers and machine builders worked a mere nine hours a day, six days a week. But employees in small workshops might labour for up to sixteen hours. Real wage levels were generally lower than elsewhere in the Austro-Hungarian Empire. So Galicia was a good place to leave. Between 1890 and 1910782000 people did exactly that, with North America the principal destination. 
Jews made up a disproportionately large group amongst the emigrants. In 1900, the Jewish population of Galicia was 812000 people, more than three quarters of whom lived in the eastern part of the province. Around seventy percent of those engaged in commerce and transportation were Jewish, in 1900. They constituted almost ninety percent of the self-employed in this sector. Over 37 percent of economically active Jews in Galicia were engaged in trade (Mahler $1952 \mathrm{p}$. 257). Jews were disproportionately concentrated in increasingly uncompetitive petty bourgeois enterprises. Despite their over-representation in urban areas, only ten percent of workers (41 254 people) were Jewish (Thon 1907 pp. 114-116). The first language of the overwhelming majority of Jewish workers was Yiddish.

Increased capitalist penetration of the countryside, in the form of improved means of communications and modern economic organization, changed and then undermined traditional Jewish social roles as intermediaries between the peasants, the Polish landowning aristocracy and urban markets. As this process accelerated toward the end of the 19th Century, large numbers of Jews were impoverished and anti-semitism emerged as a means of mobilizing the Polish peasantry politically in a way that did not challenge the capitalist order (Leon 1970).

The restructuring of the Habsburg Empire in the late 1860s had increased the autonomy of the Polish aristocracy (szlachta) in administering Galicia. It dominated the Galician Diet (Sejm in Polish, Landtag in German) in Lemberg, the only parliament in partitioned Poland. And the Austrian Empire was less repressive in its Polish province than the German and Russian Empires in theirs. Kraków was a political center for Polish nationalists and socialists from all sections of Poland. Galicia's economic backwardness was reflected in an illiteracy rate of 56 percent in 1900 (Dabrowa 1988 p. 222). But the only universities where Polish was the language of instruction were those in Kraków and Lemberg. For this reason, they attracted academics and students from German and Russian provinces of Poland. This was particularly true of the prestigious Jagiellonian University in Kraków, established in 1364, the second oldest in central Europe, although the University of Lemberg had more students.

Grossman was Jewish. His birth certificate identifies him as 'Chaskel', a Yiddish name. He was brought up in a Polish (and French) speaking household ${ }^{4}$ and was probably called 'Henryk' from his childhood. This was the personal name by which he was known throughout his public life. ${ }^{5}$ The son of a businessman, Grossman was a product of key bourgeois institutions, a privileged family, an elite school and the Jagiellonian University in Kraków. In 1908 he received his first degree, a doctorate in law, having taken courses in philosophy, economics, psychology as well as legal studies between winter semester 1900-01 and summer semester 1904. In this sense he was trained, in Gramsci's terminology, as a traditional intellectual.

At school, Henryk was already active in the social democratic movement. ${ }^{6}$ He joined the Polish Social Democratic Party (PPSD), which was formally committed to Marxism. At university Grossman continued his involvement in politics, playing a leading role in radical organizations of both secondary and university students (Myśliński 1967 pp. 90, 116; Frančić 1962 p. 81; Hass 1992; Najdus 1983 p. 434; Strobel 1974 p. 220). But he was soon active beyond student circles.

4 Christina Stead 'Jan Callowjan (Kalojan) Henryk Grossman', notes, Box 6 Folder 45, Christina Stead Collection MS4967, National Library of Australia, Canberra (Stead Collection). Stead also indicated that the family spoke French as well as Polish at home.

5 This is also likely in view of Grossman's own testimony that his father's name was 'Henryk', see Grossman's denazification questionnaire in 'Henryk Grossmann' PA 40, Universitätsarchiv Leipzig (UL) p.100. His official name change to 'Henryk', in July 1915, was noted in the birth register, Gymnasium (academic high school) and University records.

6 Christina Stead notes, Box 6 Folder 45 Stead Collection. 
Educational and mutual assistance associations of Jewish workers had first emerged in the early 1890s. Such associations organized lectures and cultural activities in Yiddish. They also performed trade union functions and became the most important links between the Jewish working class and the PPSD. Due to political repression and an economic down-turn, many of these groups declined or collapsed from the late 1890s. But the PPSD leadership did little to counteract these factors. Organizing Jewish workers was a low and neglected priority. The Party's Yiddish periodicals were, at best, sporadic and the Party did not consistently deploy Yiddish speaking agitators. According to the Australian born novelist Christina Stead, a close friend of Grossman's, during the 1940s, initially in New York, he became involved in efforts to revive Jewish working class organization in 1901 and he learned Yiddish for this purpose. ${ }^{7}$ By 1903 Grossman was the secretary of Postęp (Progress), the most important Jewish workers' association in Kraków (Buszko 1962 pp. 203-204). So, while he was doing his course work at the university, Grossman was spending a great deal of time not only on student politics but also helping build an organization that both provided a framework for successful union action and deepened its members' commitment to socialist politics, and catered to their cultural and educational needs. This connection with the Jewish labour movement in Galicia, commitment to the interests of marginalized workers and belief in their capacity to achieve their goals through struggle had a vital influence on his intellectual development.

While oriented to the working class and a component of the federal Social Democratic Workers' Party of Austra, the PPSD's leading group around Ignacy Daszyński was nationalist in outlook, giving political priority to the reunification of Poland. In this respect the PPSD followed the orientation of the Polish Socialist Party (PPS), the largest and most nationalist of the 'socialist' organizations in Russian occupied Poland (the 'Congress Kingdom of Poland' or 'Congress Poland'). Prominent in the nationalist wing of the PPS was Jozef Piłsudski, from 1926 the dictator in independent Poland. Polish nationalism increasingly shaped the PPSD's attitude to the Jewish minority in Galicia. While the Party was hostile to anti-semitism, the stock in trade of its political opponents, at its 8th Congress in January 1903, Herman Diamand, himself an assimilated Jew and PPSD leader, argued that Jewish workers should accommodate to superior Polish culture and read either Polish or Ukrainian social democratic newspapers. Given that the Party was unwilling to satisfy the considerable demand for social democratic material in Yiddish, however, the gap was filled by publications produced by the General Jewish Labour Union in Russia, Lithuania and Poland (the 'Bund'), which operated in the Russian Empire. The publications were distributed, in particular, by a Jewish social democratic committee which had existed in Lemberg since 1898 (Glicksman 1920 p. 3).

Grossman opposed the opportunism and nationalism of the PPSD on two fronts. The first was the Party's attitude to Jewish workers. He also resisted the leadership's increasingly intimate relations with the PPS in Russian occupied Poland. From 1903, at the latest, he was involved in efforts to push the Party into taking the organization of Jewish workers more seriously. He and other activists oriented to the Jewish working class argued in favor of an autonomous Jewish

7 Christina Stead 'Jan Callowjan (Kalojan) Henryk Grossman', notes, Box 6 Folder 45 Stead Collection. Stead's notes and correspondence with her partner, the financial analyst, novel and Marxist economist Bill Blake, are an important source of biographical information on Grossman. The notes, which were made with a view to or as a stage in her creative writing, have to be used with some caution. Given his family background and environment--the Grossmans lived between Kraków's Jewish quarter, the Kazimierz, and the city centre-it seems unlikely that Henryk was totally ignorant of spoken Yiddish before he decided to become involved with Jewish workers' organizations. Nevertheless, in 1907 he used Roman letters for his signature, even on Yiddish correspondence (which is written with the Hebrew alphabet), see letters of July 13 (1905) and October 9 1907, MG2 F107, Bund Archive, YIVO Archive, New York (YIVO). Leon Feyner (1948 p. 20) points out that most of the activists who contributed to Der sotsial-demokrat, including Grossman, could not write Yiddish. 
organization linked to the PPSD and the federal Austrian Party. To head off demands for a distinct Jewish organization, Daszyński convened a special conference of Jewish activists in May 1903. There, the Party leadership stressed the importance of unity, invoking the authority of Victor Adler, the father of Austrian social democracy, and the experience of the Kishinev pogrom in Russia. ${ }^{8}$ This tactic was successful. All but two of those present opposed setting up a separate Jewish social democratic party. Henryk Grossman was one of the dissidents. The PPSD leadership made a limited formal concession to Jewish militants by setting up a provincial Jewish Agitation Committee. But it was dominated by Diamand and remained a dead letter. The Party did not increase its efforts to organize Jewish workers (Piasecki 1982 p. 374; Najdus 1983 pp. 394-5; JSDP 1905e; Jobst 1996 p. 132).

It was soon clear that, despite its rhetoric at the special conference in 1903, the attitude of the PPSD leadership to the interests of the Jewish proletariat had not changed . Leaders of Jewish working class associations across Galicia, including Grossman, initiated covert preparations for an independent Jewish party at a conference in Przemysl in August 1904. They decided an immediate split would be premature, but established a coordinating committee (Kisman 1966 p. 365). Around this time, most of Grossman's student contemporaries were beginning to sit for their exams and take their degrees, after the standard four years of study. But, having completed his course work in the middle of the year, Grossman now increasingly devoted himself to full time political activity. Such an elongated undergraduate enrollment is familiar to generations of socialist students.

Antonio Gramsci's discussion of the role of intellectuals provides a useful framework for understanding Grossman's role in the Galician labour movement and the relationship between his practical experiences of working class struggle and his contributions to Marxism. Gramsci argued that each major social class 'organically' generates a specialized social layer of intellectuals which give it 'homogeneity and an awareness of its own function not only in the economic but also in the social and political fields'. This is also true of the working class. He regarded the formation of 'intellectuals of a new type which arise directly out of the masses, but remain in contact with them to become, as it were, the whalebone in the corset' of effective socialist mobilization. Such intellectuals work out and make 'coherent the principles and the problems raised by the masses in their practical activity.' 'The mode of being of the new intellectual can no longer consist in eloquence, which is an exterior and momentary mover of feelings and passions, but in active participation in practical life, as constructor, organizer, "permanent persuader" and not just a simple orator' (Gramsci 1971 pp. 10, 330, 340). They are, in other words, political activists and leaders of the working class who help it realize its interests both in immediate struggles and in socialist revolution. Gramsci, using elliptical language to avoid the prison censor, saw socialist organizations as vital to the formation and ongoing activities of the working class's organic intellectuals.

The political party for some social groups is nothing other than their specific way of elaborating their own category of organic intellectuals directly in the political and philosophical field and not just in the field of productive technique. These intellectuals are formed in this way and cannot be formed in any other way (Gramsci 1971 p. 15). ${ }^{9}$

Personal class backgrounds--whether or not they come from families that have been working class for generations--are not a consideration in distinguishing traditional intellectuals

8 Adler had a high opinion of Daszyński who was an important ally in the General Party. The German Austrian Party not only provided financial subventions for the Polish organization, Adler also acted as an intermediary in Daszyński's efforts to obtain funds from the Social Democratic Party in Germany, to enable the PPSD organ, Naprzód, to become a daily newpaper from January 1900, (Jobst 1996 p. 49).

9 For the relationship between Gramsci's conception of intellectuals and the revolutionary party see Molyneux (1978 pp. 148-154). 
from organic intellectuals of the working class. The issue is their social and political role. On the one hand many working class youths have eventually made careers as traditional intellectuals upholding capitalism through their activities in the church, universities, journalism, bourgeois labour parties etc. On the other hand Marx, Lenin, Trotsky, Luxemburg, the Bund leader Arkady Kremer and theorist Vladimir Medem, Georg Lukács and Gramsci himself came from diverse nonproletarian backgrounds. But their major contributions to Marxist theory were associated with their experience of intense periods of class struggle. They were politically formed in the course of sustained contact with the working class through their involvement in Marxist organizations. It is possible, Gramsci (1971 p. 16) argued, that 'an intellectual who joins the political party of a particular social group is merged with the organic intellectuals of the group itself, and is linked tightly with the group'. Grossman underwent the same training as many traditional bourgeois intellectuals. But, in the period from 1900 at the latest to 1904, even before he was a full-time socialist militant, his perspectives were also being shaped by his involvement in the workers' movement. He became an organic intellectual of the working class in the full sense of the term.

Grossman's growing differences with the PPSD leadership extended beyond the organization of Jewish workers to the debate over developments in the Russian Empire. The issue of the PPSD's relationship to parties in the Kingdom of Poland, in particular, increasingly assumed significance too. In 1904, the Russo-Japanese War resulted in military defeats and economic crisis for Russia. The political temperature in the Russian Empire began to rise. Apart from the PPS, there were three other socialist organizations of some significance in the Kingdom of Poland. The small PPS Proletariat was not a Marxist organization and regarded terrorism as a useful tactic. The Social Democracy of the Kingdom of Poland and Lithuania (SDKPiL), the party of Rosa Luxemburg and Leo Jogiches, was vehemently Marxist and anti-nationalist. The Bund was a Marxist organization of Jewish workers and artisans. It remained, by far, the largest social democratic group in the Russian Empire, from its formation in 1897 until 1905 (Tobias 1972; M. M. 1971 p. 1500). For the Marxist groups in Russia the increasingly militant political climate was an opportunity to propagate socialist ideas and build towards a revolution. The PPS sought to use the situation to promote Polish independence. The different political demands and positions of the socialist organizations in Russian Poland were increasingly matters of practical significance.

Grossman was prominent at the PPSD's 9th Congress in October 1904, in debates over both the Jewish Question and the Party's relationship with the PPS. The advocates of an autonomous Jewish social democratic party were defeated. So was an alliance hostile to the PPSD establishing a special relationship with the PPS, as opposed to other socialist organizations in Russian occupied Poland (Najdus 1983 pp. 400, 402). Grossman remained active in the two, overlapping opposition groups, after the Congress.

He was on friendly terms with the SDKPiL, as a member of the Kraków branch of the Fund for the Assistance of Political Prisoners and Exiles. This organization was essentially a SDKPiL front. In October 1904, he participated in a split at the Third Congress of Promien, a student organization increasingly associated with the PPS/PPSD line, to set up the Union of Socialist Youth, which included sympathizers with the Bund, SDKPiL and PPS (Proletariat). Felix Dzierżyński, at that time a SDKPiL leader based in Kraków and later a leading Russian Communist, referred to Grossman in correspondence. He seems to have been involved in smuggling literature into Congress Poland both for the Bund and the SDKPiL. ${ }^{10}$

In January 1905 Grossman published a pamphlet, The Proletariat in the Face of the Jewish Question, which articulated the outlook of Jewish militants opposed to the PPSD leadership on the 
question of a Jewish organization. Its passionate, poetic and perhaps histrionic style expressed Grossman's own feelings towards the movement he was helping to create. Opponents often encountered the sharp polemical edge of his later writing, but after this first publication he exercised much greater emotional control. It began with a critique of a treatment of the 'Jewish Question' by the well-known PPS theoretician Kazimierz Kelles-Krauz (1904). ${ }^{11}$ Against the Polish nationalist 'legend' of Jewish backwardness and cultural inferiority Grossman sustained what was essentially a Bundist position, taking issue with both assimilationist Polish socialists and Zionists. The PPSD's stance on the Jewish Question, he maintained, was an expression of opportunism, because 'opportunism in our country is capitulation in the face of prejudice and patriotic traditions' (Grossman 1905 pp. 36, 41).

By emphasizing factors which undermined the assimilation of Jews to Polish culture, Grossman adopted a deliberately one sided approach in discussing the Jewish Question in Galicia. One of the reasons he gave for adopting this method was that

For many years, in the discussion of Polonization, factors that were actually or apparently leading to assimilation were misapprehended and overemphasized, while counterposed factors were disregarded. It would be redundant to address the former again here. My task has been to point out new phenomena, not to reiterate old pronouncements. (Grossman 1905 pp. 42-43)

He engaged, in other words, in the risky, but sometimes necessary political practice of 'stick bending': the accepted position in the Party on an issue was distorted, so it was necessary to make exaggerated arguments in the opposite direction in order to bend the line straight (Grossman 1905 p. 42). ${ }^{12}$ This was an approach he employed in later discussions of Galicia's economic history and the inherent nature of economic crises under capitalism (Grossmann 1992 p. 33). Grossman regarded the continuing existence of a distinct Jewish proletariat as an important justification for an independent Jewish social democratic party, concluding that

With the achievement of an independent Jewish organization, which is the practical goal of the Jewish proletariat in its historic struggle for emancipation, the last visible vestiges of the ghetto will also disappear, to the extent that the proletariat can get rid of them under capitalism. The Jewish proletariat will only achieve equality with the proletariats of other nationalities in the Austrian social-democratic movement in this way. (Grossman 1905 p. 44)

The effectiveness of the Jewish proletariat in the struggle for socialism required its selforganization, rather than subordination to the party of a different nationality. This was impossible within the framework of the PPSD, whose leadership specifically designated their Party as Polish, not only in a territorial but also in a decisively national sense.

Events in Russia, especially after the outbreak of the revolution following Bloody Sunday, January 22 1905, in St Petersburg, gave a sense of urgency to socialist activity throughout eastern Europe. Student sympathizers of the Bund, SDKPiL and PPS (Proletariat) started publishing a journal, Zjednoczenie (Unity), highly critical of the PPSD leadership, in February 1905. The editor was Henryk Grossman. Naprzód, the PPSD's daily paper, accused him of being a swindler because Zjednoczenie was collecting funds for revolutionaries in Russia and not distributing them through PPSD channels. For Party leaders this was a welcome opportunity to get rid of a pest. They expelled him. After declarations and accusations on all sides, mass meetings, letters and petitions, Grossman, recanted, resigned as editor of Zjednoczenie and was readmitted to the Party. Naprzód, in turn, retracted some of its accusations. All this occurred within the space of a month. Grossman's apparently erratic behavior on this issue emerges as quite logical in the context of his responsibilities to the organizations of the Jewish working class. Concerned to stay in close contact with Jewish workers inside the PPSD, he had agreed to resign from the

11 For a sympathetic account of Kelles-Krauz's position, see Sobelman (1990 pp. 47-55).

12 For a description and defence of Lenin's predeliction for this methodology see Cliff (1975 pp. 66-68). 
Zjednoczenie editorial board on the urging of a meeting of 300, mainly Jewish workers, on 4 March. ${ }^{13}$

At the time of the Zjednoczenie affair, effective preparations for an independent Jewish party had hardly begun. Grossman remained within the Party in order the better to split it. But the PPSD leadership soon sniffed out the treasonous activities of the Jewish coordinating committee and went on the offensive against the basic organizations of the Jewish working class. The Galician trade union conference of 26-27 March 1905, prompted by PPSD officials, decided that the Jewish workers' educational associations and general unions should be wound up within a year. PPSD leaders now regarded these as 'nests of sedition'. With the Jewish proletariat's capacity for political and cultural activity under threat, the members of the secret coordinating committee felt compelled to act quickly. Its seat was shifted from Lemberg to Kraków, where Henryk Grossman took over as secretary (Bross 1924 p. 45; Feyner 1948 pp. 18-23; Kisman 1966 pp. 366-367). On 30 March, a meeting of 140 in the Progress association's hall resolved to signal the establishment of a new Jewish Social Democratic Party, by means of a procession of Jewish workers on May Day (Piasecki 1978 p. 40, 1982 pp. 91, 113; Najdus 1983p. 437). If the Bund, with around 30000 members, could influence events in Russia, why couldn't Jewish workers in Galicia, organized along similar lines, move into the front ranks of working class struggle?

\title{
A. Leading a new party
}

On 1 May 1905 the new Jewish Social Democratic Party of Galicia (JSDP) was proclaimed at large rallies of Jewish workers. Militants distributed the Party's founding manifesto, in Yiddish and Polish (JSDP 1905a, 1905b), and Grossman's pamphlet on the proletariat and the Jewish Question, as well as a new Yiddish newspaper, Der yidisher sotsial democrat (The Jewish Social Democrat), at the meetings.

\begin{abstract}
Speakers explained the main reasons why such a party was necessary and that Jewish workers, under the banner of their own party, wanted to fight together, hand in hand with Polish and Ukrainian workers. As an expression of this desire, processions formed under red banners after the rallies. In closed ranks the Jewish workers marched to the central assembly points and together with the Polish and Ukrainian workers later marched in common demonstrations along the main streets of the cities. In Kraków about 2000 Jewish workers marched. (Kisman 1966 p. 371)
\end{abstract}

The new Party soon had 2500 members, through the affiliation of workers' associations (JSDP 1905d). It was also known as the 'Galician Bund' and ŻPS (from its initials in Polish), while PPSD leaders and, following them, leaders of the Austrian Party referred to the JSDP as the 'Separatists'. For pragmatic reasons, the public theoretical rationale for the new Party, largely formulated by Grossman, drew on the decisions of the Austrian Party to which the JSDP sought admission. ${ }^{14}$ The Austrian Party was organized along federal lines and accepted the autonomy of constituent parties of different national groups (of which, apart from the German-Austrians, the Czechs and Poles were the largest). This principle should be extended, the JSDP's manifesto argued, to Jewish workers in Galicia too, in order that they could be effectively organized, particularly to combat Zionism:

13 The PPS archive includes documents from the controversy over Zjednoczenie, 'Sprawa Grossmana' 305/V/11 podt. 3, Zespol akt PPS, Archiwum Akt Nowych, Warsaw (PPS). The affair is also covered by Buszko (1962 pp. 234-238).

14 According to Feyner (1948 pp. 18-19) and Piasecki (1982 p. 126) Grossman wrote the JSDP manifesto (JSDP 1905a, 1905b), a document responding to PPSD attacks (JSDP 1905c), a report and an appeal to the Austrian Social Democratic Party (JSDP 1905d, 1905e). His authorship of an article published in Czech was explicit (Grossman 1906). 
We are not nationalists, we are not chauvinists, and no-one has enforced the class character of our struggle more strongly than we have. Nobody has fought Zionism as a class movement of the Jewish bourgeoisie more ruthlessly than we have. We don't want nationalist programs, we are just demanding a national organization. (emphasis in the original, JSDP 1905b p. 7) ${ }^{15}$

At the JSDP's founding congress in Lemberg on 8-9 June Grossman was elected Party Secretary. He was a contributor to and for a period the legally responsible (i.e. not managing) editor of the weekly Party newspaper, Der sotsial-demokrat (The Social Democrat) which was published in Kraków from October 1905. Later in the year he participated in a delegation to the Austrian Social Democratic Workers' Party Congress. In seeking affiliation to the Austrian Party, the Jewish socialists in Galicia were following the precedent of the Ruthenian (Ukrainian) social democrats. They were also emulating the efforts of the Bund to establish a federal relationship with the Russian Social Democratic Labour Party (RSDLP). On the prompting of the PPSD, however, the Austrian Party never recognized the JSDP. Relations between the Bund and the new Party were always close and the politics of the Galician organization were strongly influenced by its larger and older sibling in the Russian empire.

The first period of the JSDP's existence was not only one of heightened class struggle in Russia, but also Austria. Large numbers of workers took strike action. In 1905-1906, the JSDP was able to lead a series of strikes and draw new layers of workers into the labour movement. In some cases, like the Lemberg bakers' dispute in mid 1905, this involved Polish as well as Jewish workers. ${ }^{16}$ For three years Grossman was fully and intensely involved in the socialist workers' movement as a political leader, though he received no salary from the Party. The JSDP's first four congresses re-elected Grossman to the Party Executive and he represented his Party at the Bund's 7th Congress in September 1906 (Hass 1992; Bunzl 1975 p. 100). But his activity as a JSDP leader was not confined to theoretical, diplomatic and administrative work. He also continued to be involved in the most basic kind of practical organizing: addressing meetings, contributing to the Party press and winning new recruits.

This could involve physical danger. When the Party was setting up an organization in the town of Chrzanow, about 45 kilometers west of Kraków, JSDP speakers and agitators visited from the metropolis to help build the branch. Organizing was tough. The local bosses were Hassids (members of a fanatical Jewish sect) and dominated their underpaid employees not only at work, but through their control of the Jewish community. They did not welcome outside agitators who disrupted this paternalist and (for the employers) profitable order. And outsiders, especially well-dressed gentlemen amongst traditionally bearded and clothed locals, were not difficult to pick. When Henryk Grossman came to support the activities of his comrades, the Hassidic zealots incited a large crowd to beat him up. He had, however, not only had a Party behind him, but also the advantages and connections of a middle class law student. He initiated legal action. In court Grossman accused the pious, parochial despots, motivated by their wallets, of using religion to incite the assault. His success in the Chrzanow court turned the affair into a victory for the JSDP and a publicity coup (Kisman 1966, p. 383). ${ }^{17}$

In May 1906, the JSDP's second Congress called for national cultural autonomy for Yiddish speaking Jews in Austria. This occurred once it was clear that the prospects for affiliation to the Austrian Party were slight and after the Bund had formally incorporated the demand for national

15 For an account of developments in Galicia during this period, from a labor Zionist perspective see Reiss (1973).

16 Yidisher sotsial demokrat 4-5, July-August 1905 p. 47.

17 Also see the leaflet, 'Khaveyrim! Yidishe Arbeter!', MG7-29, YIVO; Sotsial-demokrat May 171907. Christina Stead's story 'The Azhdanov Tailors' provides a fictionalized account of the episode (1986). 
cultural autonomy for Jews in the Russian Empire into its program in October $1905 .{ }^{18}$. Bundists had justified this demand for some time with reference to the work of the Austrian social democrat Karl Renner. Renner (as 'Rudolf Springer' and 'Synopticus') argued that the nations of the Austrian Empire should be organized on the model of the churches. It should be open to people to make an individual decision about the nationality they belonged to and supported financially. This was also known as the 'personality principle' (Renner 1899, 1902), Otto Bauer's The National Question and Social Democracy developed an extensive rationale for Renner's approach, using a more Marxist terminology. But Bauer made a special effort, in the chapter following his outline of 'the personality principle', to quarantine the Jewish Question from his general conclusions. This was explicitly designed to ensure that the Galician 'separatists' could not make use of them (Bauer 1907 p. 318).

\title{
B. The influence of the Bund
}

In 1907, Grossman explained the influence of the Bund on his own organization in the pamphlet Bundism in Galicia

\begin{abstract}
We can say that without the Bund we would not be what we are. We are grateful that the Bund's literature has not only satisfied the needs of the whole Jewish working class, but particularly the intellectual needs of the Jewish working class here. The Bund with its literature and its experience, taught the Galician working class how to adjust the general socialist doctrine to the particular conditions of Jewish society. And thanks to this, the 'solution' to the Jewish Question was transferred from the nebulous sphere of the maximum socialist program--to which it had been confined--to that of practical action, and political struggle for social and national liberation of the Jewish working class.
\end{abstract}

In breaking with the PPSD's mechanical approach, Grossman expressed the connection between the struggle against the exploitation of Jewish workers and their oppression as Jews by harking back to Marx's fundamental and distinctive conception of socialism,

The words of the Communist Manifesto that '... the emancipation of the workers must be the act of the working class itself...' mean, as far as the Jews are concerned, that their emancipation can only be the product of their own political struggle. (Grossman 1907 pp. 45, 47)

In this period, strategies to combat the kinds of persecution faced by Jewish workers were not only being discussed by socialists in eastern Europe. Amongst nationally oppressed workers, other Marxist theorists and organizations were identifying the activity of oppressed workers themselves as a central element in this struggle. A few years earlier, on the other side of the continent, James Connolly had conceptualized the liberation of Irish workers in remarkably similar terms to those used by Grossman. ${ }^{19}$

There were, however, major debates about how Marxists should address the 'national question'. Involvement in the Galician socialist movement exposed Grossman to a range of these. He had personal, if less than friendly, contact with senior PPSD figures. He had met the leaders of the Austrian Party in Vienna. He was familiar with the work not only of Austrian Marxist theorists but also with the literature of the German Party and of its senior theoretician, Karl Kautsky, in particular. Through student politics he had developed links with a range of different left wing currents in Congress Poland. But it was Grossman's experience in building and leading the organizations of the Jewish working class in Galicia that particularly shaped his views. In these organizations he functioned as an organic working class intellectual in a strong sense:

18 For a more detailed account of the development of the JSDP's position on the national question and its relationship to the stances of other currents in central and eastern European Marxism see Kuhn (1998a).

19 'The Irish working class must emancipate itself, and in emancipating itself, must, perforce, free its country ... The freedom of the working class must be the work of the working class' James Connolly Erin's hope 1902 edition cited by Howell (1986 p. 42). 
elaborating a coherent rationale for the JSDP's existence, program and activity, while engaged in practical struggles over wages, conditions, universal suffrage and against national oppression.

In Galicia, the Bund's position on party organization made, if anything, more sense than in Russia. The RSDLP and the Bolsheviks, in particular, consistently opposed the chauvinism of the Russian Empire's dominant nation and defended the civil, including language rights of the Jews and national minorities. The PPSD's politics were increasingly dominated by Polish nationalism and the Party's leaders had little interest in opposing the cultural oppression of Jewish workers. After PPSD's 1904 Congress, Grossman and other Jewish militants were faced with the choice of seeing the social democratic organizations of the Jewish proletariat disappear or transforming them into an independent party (Kuhn 1998b, 2000).

In view of Grossman's subsequent political evolution, it is worth outlining the relationship between the Bund and Bolshevism. The political distance between these organizations in the period before 1907 has often been exaggerated by an exclusive focus on Lenin's campaign, from 1902, against the Bund's federalism and position on the national question (Bunzl 1975 p. 90). Where the Bund argued that the RSDLP should be a federation of national organizations, Lenin maintained that it should have a unified structure. In relation to the question of national oppression, the Bund favored the demand for national cultural autonomy. Lenin, while demanding civil rights for Jews, including linguistic rights, stressed the importance of the right of oppressed nations to secede from states dominated by oppressor nations. Secession was not a possibility for the dispersed Jewish population.

While these differences were significant, in terms of political tactics during this period, the Bund's position was often closer to that of the Bolsheviks than the Mensheviks (Yago-Jung 1974 p. 24). For example, in June 1905, reporting on the lessons of the Russian revolution, the JSDP's organ, Der yidishe sotsial-democrat, affirmed that the proletariat was leading the revolutionary struggle in Russia. This position was no doubt gleaned from the Bund, but was commensurate with the Lenin's analysis. ${ }^{20}$ Unlike the Mensheviks, both the Bund and Bolsheviks called for a boycott of the elections to the First Duma in August 1905, given the Duma's token powers and the continuing development of the revolution. Nor, unlike the Mensheviks, who pinned considerable hopes on Russian liberalism, did the Bund have any illusions in the progressiveness of the Jewish bourgeoisie. During this period the distinctive feature of the Bund's politics, compared the Bolsheviks, was confined to its stance on the national question rather than the role of the working class in the revolution. It was the Bund in this period that had the greatest impact on Grossman, as his commitment to Marxism was tested in confrontations not only with the capitalist class and the Austrian imperial state, but also with the opportunism of the PPSD and the Austrian Party. Only later, after the defeat of the revolution in Russia, during the 'years of reaction', 1907-1910, did much of the Bund's leadership move to the right and into the Menshevik camp (Tobias and Woodhouse 1985 p. 141). ${ }^{21}$

20 The article also included a much less plausible argument for the significance of the Bund, with a base in the small towns of the Pale, in the revolution; the author claimed that an era of decentralized proletarian revolutionary forces, a 'modern revolutionary Vendee', had opened, 'Di lehren der revolutsion', Der yidisher sotsial-demokrat 4-5, July-August 1905, pp. 2-7. On the Bolshevik position in precisely this period see Lenin (1905 pp. 425-427).

21 From 1907 the membership of all Russian social democratic organizations collapsed. On the shift of the majority of the Bund's leadership towards the Mensheviks, see Abramovitch (1955 p. 391). This association continued through the revival in the level of class struggle from 1911 and the final break between the Bolsheviks and Mensheviks in 1912 to the revolutions of 1917. 


\section{Research in Vienna and wartime activity}

The defeat of the ' 1905 ' revolution in Russia had consequences in Austria-Hungary too. Mass action in 1905 had forced the regime to concede universal suffrage for elections to the imperial parliament (Reichsrat). But by the time the first elections under the new law were held in 1907, the labour movement was on the defensive and soon after the Austrian Social Democratic Party began to break up. No further federal congresses were held. A recession also gave employers and their recently established organizations the advantage in their struggles with the unions.

\section{A. Vienna}

Grossman's behavior seems to match this pattern of retreat. According to the Leksikon fun der nayer yidisher literatur, 'in 1908 [Grossman] settled in Vienna and withdrew from Jewish life in general' (Leksikon 1958 columns 354-355). It is true that Grossman took his three final university exams in July 1907 (law), July 1908 (politics) and November 1908 (history) apparently in preparation for his departure from Kraków. In Vienna, on 1 December 1908 he married the 25 year old Janina Reicher, from Russian Poland via Kraków. ${ }^{22}$ In the imperial capital, he embarked on the seven-year legal apprenticeship required before he could set up in practice as an advocate while Janina developed her skills as a painter(Maurin-Bialostocka 1975). In practice, Henryk engaged in academic research with the encouragement and support of Carl Grünberg, the first professor with Marxist inclinations at a German speaking university (Grossmann 1914 p. x). He soon began work on a major study of Austrian trade policy in Galicia in the late 18th Century. This involved extensive archival research in Vienna, Kraków, Lemberg and Paris. The project gave rise to a series of publications, culminating in 1914, with a book of over 500 pages, intended to be the thesis for his higher doctorate (Habilitation), the license necessary for teaching at a university (Grossman 1911a, 1912; Grossmann, 1911b, 1913, 1914).

These activities, together with new family responsibilities (his first son was born in Paris on 16 August 1910, his second on May Day 1914 in Vienna) no doubt entailed a lower level of political involvement. But Grossman's departure from Kraków did not involve a complete break with politics. In February 1910 he delivered a lecture on the economic history of the Jews in Galicia to the Ferdinand Lassalle Club in Vienna. The Club was a social and educational association of JSDP members in the Habsburg capital. ${ }^{23}$ The JSDP Congress in Lemberg received a telegram from Grossman in Paris and returned him to the Party Executive, in October 1910. But he was not elected to the Executive by the special Congress in October 1911 which unified the JSDP and the small Jewish section of the PPSD (Sotsial-demokrat November 11 1910). As the most prominent leader of the 1905 split, it was convenient that Grossman was not active in Galicia to cast a shadow on the (short-lived) thaw in relations between the JSDP and PPSD. The left in the German Austrian Social Democratic Workers' Party was not an attractive alternative for him. It was weak. And its position on the national question, articulated by Josef Strasser (1912), was, like Luxemburg's, both principled and abstract, failing to distinguished between the nationalisms of oppressed and oppressor nations. Grossman was politically isolated.

Although no longer actively involved in politics, in 1912 Grossman did make an intervention in a dispute inside the Polish, German and Russian social democratic movements. This related to his role, in 1904, as the chairperson of an inquiry by socialist students into accusations that Karl Radek had stolen books from comrades. The commission had exonerated Radek, with whom Grossman had worked in the student organization Ruch. During the '1905' revolution in Russia,

22 Marriage certificate, 341/I/1908, Israelitische Kultusgemeinde Wien, Matrikelamt.

23 Leaflet advertising talks at the 'Jüd. Arb.-Bildungs Verein "Ferdinand Lassalle", Folder 130, MG2, YIVO. I am indebted to Jack Jacobs (1998) for drawing my attention to Grossman's relationship with the Lassalle Club. 
Radek became a prominent member of the SDKPiL and later of the German left (and eventually of the Russian Communist Party). In 1912 a faction fight broke out in the SDKPiL over the ineffective and authoritarian leadership of the SDKPiL Executive under Jogiches, to whom Luxemburg remained loyal. Radek, then working as a journalist for the German social democratic press, supported the 'Splitters' faction against Jogiches, who organized for Radek's expulsion on the basis of the 1904 allegations and other stale charges. The right wing of the German Social Democratic Party (SPD) was only too happy to take the issue up in order to rid itself of a bothersome critic. Grossman learnt of an inquiry initiated by German leftists in Bremen into the Radek Affair from the SPD's flagship newspaper, the Berlin Vorwärts. He quickly wrote a statement for the investigators outlining the results of the Kraków commission and described the revival of the accusations against Radek as 'malicious' ${ }^{24}$

Apart from his contribution to the Radek Affair, no sources which shed light on Grossman's political activity and evolution during the decade after 1910 have survived. His publications of the period, on Galician economic history and the history of official statistics in Austria, were largely empirical. But none was incompatible with a Marxist perspective and some clearly reflected his political views. As these publications were intended as steps towards an academic career, Grossman's caution about explicit references to Marxism are understandable. The conservative nature of Austrian universities (and most universities anywhere at that time!) precluded open avowals of Marxist politics until after an appointment had been secured. Grünberg's career provided an object lesson. He had never been a member of the Social Democratic Party and his public identification with Marxist methodology in 1907 explicitly rejected the theories of concentration, immiserization and crisis attributed to Marx. But Grünberg's political sympathies still meant that he was only 'appointed to a full professorial chair, against considerable opposition' in 1912, at the age of 51, after decades of academic experience, including a long series of major publications and extensive teaching experience (Wiggershaus 1993 p. 22; Migdal 1981 p. 69).

In January 1912, Grossman published a long article, which had been presented as a progress report to the 5th Conference of Polish Economists. In doing this he drew his research project to the attention of a Polish public, which was the main audience for both its academic and political conclusions. This study of the industrial and commercial policy for Galicia under Empress Maria Theresia, to 1780, and then Emperor Josef II, between 1772 and 1790, dealt with issues that were particularly sensitive for the Polish national movement in all its colourations, from Russophile conservatives to the nationalist current in the socialist movement, represented in Galicia by the PPSD.

Contrary to the nationalist orthodoxy, Grossman argued, Habsburg commercial and trade policies in Galicia under Maria Theresia and Josef II had not been designed to hinder economic development and turn the province into a colonial market for goods from the Empire. On the contrary, apart from the damaging effects of Josef's policies towards the Jews, the enlightened absolutist monarchs pursued mercantilist policies designed to promote Galicia's trade and industry and, in fact, contrasted favourably with the feudal order of the Polish Republic which had undermined industry and urban centres. Grossman's conclusions, which indicted the Polish nobility and Josef's successors for Galicia's backwardness, were also implicitly at odds with the views of the conservative Kraków School of historiography, represented by Michał Bobrzyńskiin particular. Its empirical work was used to support Austrian rule and the domination of the

24 Declaration by Henryk Grossman on the Radek Affair, Vienna 17 September 1912, Henke Nachlass, Archiv der sozialen Demokratie der Friedrich-Ebert-Stiftung, Bonn (Henke). Strobel's magnificent and very detailed study of Polish social democracy (1974) constitutes the main source for the account here. Also see Tuck (1988) and Heym's fictionalized account (1995). 
province by the old Polish ruling class (Grossman 1912 pp. 1-8). ${ }^{25}$ There was a Bundist shape to Grossmans argument, conducted in terms of conflicting material class interests, directed against Polish chauvinism and a reactionary imperial state, and concerned with the negative consequences of the persecution of Galician Jewry. This work, or one closely related to it, won Grossman the Julius Wawelberg prize in the Philosophy Faculty of Lemberg University. ${ }^{26}$

In September 1913, Grossman completed Austria's Trade Policy with Regard to Galicia during the Reform Period of 1772-1720, which presented the results of his research at length (Grossmann 1914). Dedicated to 'my wife Janka', the book was published, just days before the outbreak of the First World War, as the tenth volume in Grünberg's 'Studies on social economic and administrative history' series. ${ }^{27}$ It incorporated the material and arguments of his earlier publications on Galicia with full references and spelt out the details of Habsburg mercantilist policies designed to increase the value of Galicia to the Empire by promoting economic activity and trade.

The structure of the book's argument recalled Grossman's approach in The Proletariat in the Face of the Jewish Question by adopting 'quite consciously, in a certain sense a devil's advocate' position against another nationalist 'legend': that Austrian occupation held back Galicia's economic development. The lack of previous critical historical work in this area, the scale of the subject matter and limited space meant that the text 'on the one hand is overburdened with detail and on the other is nevertheless often only able to offer overviews' (Grossmann 1914 pp. ix-x, 3-10). As he made use of some archival sources which have since been destroyed, this burden of details has benefited subsequent researchers. In the spirit of Marx's critique of the fetishism of commodities as an explanation of ideology, Grossman also provided a materialist account of the legend itself, which served the interests of the Galician nobility for whom, 'in contrast to the good old days, the decline in grain exports to Danzig [under the Habsburgs] appeared as a collapse in trade per se' (Grossmann 1914 pp. 452-454).

While he certainly knew about Grossman's political activities in Galicia, Jakob Pistiner warned readers of the Austrian Social Democracy's theoretical journal that the book 'has to be read critically, because it is not based on the materialist conception of history' (Pistiner 1915). However, much later, Grossman claimed that his study of Austrian trade policy in Galicia was 'written from the standpoint of historical materialism' ${ }^{28}$ Despite his failure to mention or reference Marx or any other Marxists, this seems a fair claim. The language of the preface and the larger examination of 'the transition from the traditional to the modern mode of production', which it outlined as the book's context, tacitly expressed a Marxist framework. So did the materialist and class analysis of the main text. The Marxist Roman Rosdolsky in his studies of $18^{\text {th }}$ century economic reform in Galicia drew on and endorsed Grossman's analysis. In fact, Rosdolsky undertook some of the analysis which the preface to Austria's Trade Policy promised for a sequel that never appeared (Rosdolsky 1992 pp. 12, 21, 33). The concluding statement in Grossman's book, moreover, was very much in the spirit of a long term Marxist analysis

The Austrian bureaucracy of that time, so unpleasant for many, was thus for Galicia the instrument of an objectively unavoidable historical process. An unprejudiced assessment must concede that the mercantilist economic policy of the Austrian regime in the newly won territory, taken as a whole and

25 For some brief comments on the development of Polish historiography see Tyrowicz (1964 p. 486).

26 Henryk Grossman 'Curriculum vitae', Akta Osobowe Henryka Grossmana, p. 1, Centralna Biblioteka Statystyczna, Glowny Urzad Statystyczny, (GUS); Henryk Grossmann, Curriculum vitae, Akten der WiSo Fakultät, Sig $45^{2}$ Abt 150 Nr 376, Archiv der Johann Wolfgang Goethe Universität, Frankfurt am Main (UFM), p. 198, indicates that the prize was awarded in 1910.

27 Carl Grünberg 'Gutachtlicher Bericht. Betr. Habilitation des Dr Heinrich Grossmann. 27 Januar 1927', UFM, pp. 212-215.

28 'Lebenslauf', UL pp. 64-66; also see 'Assessment', 14 August 1950, UL. p. 57. 
apart from mistakes which are of lesser significance, was historically unavoidable and therefore justified. It bore the possibilities of succeeding and was therefore in essence useful and, from the stand point of the territory's interests, desirable. (Grossmann 1914 p. 475)

\section{B. The First World War}

During the War the potential for Grossman to engage in political activity was severely restricted, particularly after he was conscripted in 1915. Galicia was one of the main battlefields of World War I and the JSDP rapidly ceased to function. Its revival only began in autumn 1917 after the Russian revolution had taken the pressure off the eastern front (Kisman 1966 p. 475).

Grossman followed the normal privileged trajectory of an educated man in the AustroHungarian army: he was promoted through the non-commissioned ranks and eventually received a reserve officer's commission. After a brief period at the front he was recruited to the Ministry of War's Expert Committee for the War Economy (Wissenschaftliche Komitee für Kriegswirtschaft). He became the Committee's delegate in Lublin, the seat of the Austrian occupation administration's 'General Government' in the Kingdom of Poland and later worked for it in Vienna. One of the memoranda he produced for the Committee, a study of the national wealth of occupied Poland, was later published in Warsaw (Grossman 1922b). Despite his military service, Grossman also managed to publish a monograph-length article in 1916 and a substantial essay in 1917. The first, and a subsequent response to a critic, dealt with the origins of official statistics in Austria, the second with the organization of credit in Congress Poland before the War (Grossmann 1916a, 1916b, 1917).

As in Austria's trade policy, few Marxists inhabited the extensive references and footnotes of the study on the origins of Austrian statistics, which also provided summaries of early census collections. In addition to career considerations, Grossman's status as a soldier on active duty and the study's appearance in an official publication constrained the explicit expression of political views. But there was evidence to confirm Grossman's later claim that this book, too, was written from an historical materialist perspective. ${ }^{29}$ Thus he justified his method in the essay in terms compatible with both the standpoints of Marxism and of the German Historical School of economics, with a quotation from Karl Theodore von Inama-Sternegg, one of the fathers of modern official statistics in Austria, 'Every situation is only to a small extent a direct product of the relations which at the time surround it; most significantly it is an expression of the life and effects of the social forces of an earlier period'. This quotation was supplemented by one from Karl Renner, then the leader of the pro-war right wing of Austrian social democracy, to the effect that 'every land and people carries the ruins of its history for decades and centuries; states and nations also suffer from inherited diseases [sind erblich belastet]' (Grossmann 1916a p. 332). This expressed Grossman's political outlook in a well crafted ambiguity: patriotism and/or profound skepticism about the Austrian state. It reemerged in the final words of the quotation from the enlightened statesman and advisor to Maria Theresia, Baron von Borié, which concluded the work: 'Austria above everything, if only it wants' (Grossmann 1916a p. 421).

While liaising between the General Government in Lublin and the Scientific Committee, Grossman must have spent considerable time in Vienna. So 'Dr. Henryk Großmann in Wien' was well placed to contribute an account of the organization of credit in the Kingdom of Poland to a collection of lectures from a course on the Kingdom of Poland before the War, published after June 1917 by the Viennese Free Association for Further Education in Political Science. The prearranged speaker on 'Banks and the cooperative system' was not able to participate in the lecture course in March and Grossman's comprehensive essay was inserted to ensure that the same gap did not occur in the publication. All but possibly one of the contributors were Polish, six 
were professors at the universities in Kraków and Lemberg, including Josef Buzek who was a member of the Reichsrat and headed the Austrian Statistical Bureau in Galicia.

The course touched on an issue of immediate political concern after German military successes had expelled Russia from Poland: the question of Poland's future. Developments in the Kingdom of Poland became a matter of urgent interest both for the Austrian Government, with its unrealizable hopes of influencing Polish affairs, and for supporters of Polish independence. On 5 November 1916, Germany and Austria had granted the Kingdom of Poland 'independence', hoping to win some popular support there for their military efforts. In practice their military administrations remained in place and continued to exercise tight control over the region. Grossman's essay provided not only a systematic account of the development of credit institutions and arrangements in the Kingdom, but also a diagnosis of their weaknesses and a series of policy recommendations (Grossmann 1917).

He began with the assertion that it was not possible to understand the organization of a country's credit separately from other aspects of its economy, acknowledging the 'competence and great service' of those who built up the Kingdom's credit institutions under politically unfavorable circumstances. An outline of changes in the credit system from the Napoleonic period followed, in which he examined its relationship to large landowners; the peasantry, in the aftermath of the their liberation in 1864; industry and commerce; municipal needs; credit cooperatives; and institutions for small depositors. Grossman favoured greater state intervention in a number of areas. Thus he used land reform in Ireland as an example for the solution of the problem of landlessness and uneconomic small holdings in Poland. And his main policy conclusions were recommendations for the public provision of credit against real assets to all social groups, on grounds of social policy; encouragement of a check payment system to free money from circulation for investment; and, in the face of disturbances caused by international money markets and the previous absence of any unified bank policy in the Kingdom of Poland, the establishment of a central bank to manage credit 'in the interests of increasing the productive forces of the country and its whole economy' (Grossmann 1917 p. 208).

While the analysis did highlight the significance of class relations in agriculture, it too was politically circumscribed by its appearance during the War in a book concerned with conventional public policy. Nevertheless, state control of the War economy meant that Grossman could make radical proposals for state action. Two elements, however, introduced a revolutionary theme, if in an oblique fashion. First, in 1917, given the paucity of news on Ireland, any mention of that British colony would trigger in an Eastern European audience associations with the Easter 1916 rising in Dublin, particularly after the February Revolution (March, according to the modern calendar) in Russia brought down the Tsar. Grossman, secondly, dwelt lovingly on the effectiveness of workers' action at the high point of the ' 1905 ' revolution in his account of the solidity of Polish financial institutions in crisis situations! 'The strike movement in 1905 halted the entire economic life of the country, trade and exchange faltered, horrendous amounts of goods spoilt in transit, payments could not be made and various firms collapsed' (Grossmann $1917 \mathrm{pp}$. 189, 204).

Grossman's post as a specialist on social policy with the Scientific Committee was an excellent jumping off point for a civilian career when, in the autumn of 1918, revolutions in Germany and Austria were bringing down the Empires and ending the war. A senior appointment (as Hofsekretär) in the Austrian Central Statistical Commission was 'long prepared for and imminent'. After the anticipated acceptance of Austria's trade policy as his Habilitation thesis, which Grünberg was organizing at the Viennese Faculty of Law and Politics, ${ }^{30}$ such a job could be 
combined with academic pursuits and university teaching, and hence provide a well remunerated path to securing a professorial chair. But the limited form of the Austrian revolution meant that Grossman could not pursue his career plans in Vienna. Although the Social Democrats were the largest party in the coalition government which took power in Austria, the new regime adopted a definition of citizenship designed to create a sense of loyalty to rump Austria by reinforcing prejudices against 'foreigners'. Only people who were formally registered as residents on the territory of the new state before the War were citizens. People who officially registered later could become citizens, with the exception of those from Dalmatia, Istria or Galicia. The provision was primarily designed to prevent roughly 35000 Galician Jews from staying in Vienna (Wróbel 1994 p. 135). All parties in the provisional National Assembly 'agreed that rules had to be found to make it impossible for Jewish refugees who were in German Austria to become citizens' (Grandner 1995 p. 63; also Carsten 1986 p. 30).

\section{A career in Warsaw and a return to active politics}

His career stymied in Vienna, in 1919 Grossman moved to Warsaw, the capital of the revived Polish Republic. There, on 1 December, he took up a senior appointment in the Polish Central Statistical Office (GUS). He was soon in charge of theoretical and administrative preparations for the first Polish census and published several statistical studies (Grossman 1920, 1921, 1922b). Grossman also became involved in active revolutionary politics again, joining the Communist Workers Party of Poland (KPRP) in 1920. ${ }^{31}$

Some time after 1910, presumably under the influence of the October 1917 revolution in Russia, Grossman was persuaded by the Bolsheviks' theoretical and practical innovations in Marxist politics. ${ }^{32}$ We do not know when he began to accept the positions of the Bolshevik/Communist Party and whether his sympathies for them predated 1917. Certainly, many former Bundists in Poland and Russia followed a similar path. Grossman's orientation to working class self-activity and direct experience of the capitulations to national chauvinism by the leaderships of the PPSD and the Austrian Party no doubt predisposed him to the Communist critique of opportunism and 'social imperialism'. To him, as to millions of workers and socialists, the Bolshevik Revolution came to reaffirm the possibility that radical working class politics could be practical and successful.

The end of the War had seen an upsurge in both revolutionary working class activity in Poland and in Polish national sentiment. Soviet Russia and the Soviet Ukraine were on the other side of two of the new Polish state's still disputed borders. Communists were regarded as traitors to Poland, not only by the reactionaries of the National Democratic Party, but also the followers of Piłsudski, the first head of state, and the PPS, now led by Daszyński.

An openly Marxist and revolutionary position was already apparent, however, in a paper Grossman read at the Polish Academy of Science on 16 June 1919 (Grossman 1922a). This outlined his views on Marxist crisis theory. In the space of five pages, Grossman made a series of observations about Marxist economic method and theory, being concerned to establish "whether

31 Henryk Grossmann 'Lebenslauf von Professor Dr. Henryk Grossman’ UL pp. 61-63; 'Lebenslauf' UL pp. 6466. This account, made almost a quarter of a century after he had left Warsaw, is not entirely accurate. He claimed to have established the 'Workers' University' in Warsaw, an event which predated his arrival there by several years. Grossman also mistakenly asserted that that he left Poland after the Piłsudski coup (in 1926).

32 During the Radek Affair, Grossman had already, though probably unwittingly, supported Lenin. Lenin supported Radek and the 'Splitters' in part to counter Jogiches's political ambitions in the RSDLP. Jogisches was trying to establish his own authority and that of the SDKPiL in the RSDLP as an arbiter between the Bolsheviks and Mensheviks (Strobel 1974). 
the crises result from the essence of the existing economic order, or whether they are the result of inessential and accidental influences'. Rather than seeking a solution in detailed descriptions, Grossmann was of the opinion that

\begin{abstract}
naïve empiricism must be abandoned and--experiments being out of the question--logical constructions must be attempted. As a physicist investigating the fall of bodies examines, in his desire to exclude the accidental and external influences of the air, the fall of bodies in vacuo, under conditions created artificially, so the question of whether crises result from the essence of the economic mechanism under consideration can only be explained when we make this mechanism independent in our thought of the disturbing influences of foreign markets and investigate it as existing for itself, as if in a vacuum. (Grossman 1922a pp. 285-286)
\end{abstract}

This approach entailed Grossman's understanding of Marx's own method and his implicit critique of Rosa Luxemburg's argument that capital accumulation can only be sustained by the existence of non-capitalist markets.

Before the War, Otto Bauer, following the Russian economist Tugan-Baranovski, had demonstrated that capitalism would not break down so long as the right proportions were maintained between different departments of production. Bauer's argument, which Grossman endorsed, was directed against Rosa Luxemburg. Grossman implicitly departed from Bauer in two respects. First, Bauer had concentrated on the maintenance of proportionality between the size of the working population and investment in variable capital (wages). Changes in wage levels, Bauer maintained, brought the system back into full employment equilibrium. Particularly when cartels exist, however, this mechanism will not necessarily operate. Grossman emphasized, following Marx, that during crises the assets of bankrupt firms are sold off at below their historical value and, thus devalued, can be profitable for their new owners.

Grossman's second departure from Bauer was supplementary rather than critical.; Grossman offered a new explanation of why disproportionality arises under capitalism and gives rise to economic crises. He did so by stressing an issue that had been neglected after Marx: the contradiction between commodities as items with specific uses (use values) and commodities as the embodiment of specific quantities of labour, produced for profit (exchange values).

Proportionality in production had to keep the production of different use values in balance, as the specific qualities of commodities mean that they can only be consumed when they are brought together in the right ratios, as with the number of cars and the number of car tyres produced. On the other hand, proportion also has to be maintained among the values of different commodities in production, notably the value of labour power in relation to the value of constant capital (machinery, equipment, raw materials) to ensure that profits are made (Bauer 1913). ${ }^{33}$

The sophistication of Grossman's short paper indicated considerable familiarity with and thought about Marxist economics. Already while living in Kraków, Grossman had read Die Neue Zeit, Kautsky's journal, which provided one of the most important arenas for discussion and debate, including over economic theory, in the international social democratic movement. From 1919, at the very latest, Grossman began a systematic exploration of Marxist economic theory which continued until his death in 1950. During the 1920s, proponents of disproportionality theory such as Bauer and Rudolf Hilferding (the Austro-Marxist author of Finance capital, on which Bauer's arguments about disproportion drew was also German Finance Minister on two occasions during the twenties) came around to the position that state intervention might be able to

33 In 1910, Hilferding had, in an aside, pointed out that stable capitalist development requires both appropriate 'value magnitudes' and 'specific use values which must possess definite qualities in produciton and consumption', 1910 pp. 284-285. In the course of the 1920s, Grossman developed a different explanation of economic crises to underpin his revolutionary politics. This centred on the tendency for the rate of profit to fall and used a modified version of Bauer's model of reproduction against Bauer's own economic and reformist political conclusions (Grossmann 1928 p. 185, 1929a). 
maintain the right proportions in production and therefore prevent economic crises (Howard and King 1989 pp. 272-273). Grossman, on the other hand, insisted that crises were an intrinsic feature of capitalism and developed his insights about Marx's methodology and the distinction between use and exchange value. Later in the decade he elaborated different, more secure foundations for his argument about capitalist crises (Grossmann 1929a, 1992). The point of his argument, in 1919 and 1929, remained the same, to provide, as Rosa Luxemburg had attempted to, a foundation in Marxist economic theory for revolutionary working class action.

\section{A. At the Central Statistical Office}

Jozef Buzek, who became the founding head of the GUS in 1919, had been the President of the Austrian Statistical Bureau in Galicia, evacuated along with other government agencies from Lemberg to Vienna during the War. He was familiar with Grossman's work, at the very least because both had contributed chapters to the 1917 book on the Kingdom of Poland (Ćwikliński 1917). He appointed his co-contributor to a responsible position. By March 1920 Grossman had been promoted a step, to the senior post of Ministerial Councilor in the GUS. ${ }^{34}$ Even though Buzek was a member of the middle-of-the-road Piast peasant party, the GUS under his leadership was a refuge for leftists. Stefan Szulc, for example, held a senior position and was a covert sympathizer of the KPRP, as was Ignacy Weinfeld who edited the GUS's first publications. Stanisław Tołwiński then an unaligned Communist and Mieczysław Kwiatkowski, a Party member, joined the agency after Grossman departed in 1921 (Tołwiński 1971 pp. 172, 175-176).

Grossman was in charge of preparations for Poland's first population census. The census was a huge operation, employing around 60000 census collectors alone (Grossman 1920 pp. 88, 96). In the first volume of the GUS's journal, Grossman outlined the significance and tasks of the Polish census, using census results and commentaries from Austria, Germany, France, Britain, the Philippines and Switzerland (amongst others). The article outlined the main features of the census: its legislative basis; its timing and frequency; the relationship between forms and individuals; and the use of census collectors. Given the urgent need for a wide range of information, the census collected not only data on population but also employment, livestock, buildings and enterprizes. In discussing specific questions on the census form, Grossman devoted considerable space to technical aspects of collecting information about employment and religion. He justified a focus on formal religious affiliation rather than religious beliefs,

We are no more interested in the religious convictions of people than in their general philosophical
or aesthetic ones, such as regarding the immortality of the soul or the artistic value of the poem 'Pan
Tadeusz'. If we do not ask these important questions in the census, but we ask about religion, it is
because this question throws light on some other social issues. (Grossman 1920 p. 99)

The depth of feeling aroused by the question of language, going back to his own experience as a member, if at a distance, of the JSDP leadership during the campaign against the Austrian census of 1910 was clearly expressed.

On the issue of language spoken, the census totally rejects the Prussian and Austrian traditions and opts for an objective analysis. The Austrian instructions for census collectors ... reads: 'For each Austrian citizen the language that he/she uses daily should be reported. However, only one language should be stated from those listed below ...' This census does not restrict answers but aims at finding the truth. (Grossman 1920 p. 100)

Polish nationalists would have shared these views in relation to the German Empire, where the Polish language had been suppressed before the War. But the conduct of censes in the Galicia had been an aspect of the repression of the Ukrainian and Jewish minorities, designed to maximize the number of 'Poles' (defined as Polish speakers) and hence funding for education in the Polish 
language. For the purposes of Austrian censes the Yiddish language did not exist. In its fight against the national oppression of Jewish workers, the JSDP played a prominent role in a campaign to persuade Yiddish speakers to ignore the regulations and to specify Yiddish as their language in the 1910 census. Some of the transgressors were fined and, when they refused to pay, jailed (Sotsial-demokrat November 11 1910, December 9 1910; Kisman 1966 pp. 423-424). So Grossman's condemnation of Austrian census practice was significant. But he did not touch directly on the most politically sensitive aspect of the census, or for that matter of any task the GUS was to undertake: the question of nationality.

In his article, Grossman had pointed out that only a few months' preparations were being undertaken for the Polish census scheduled for autumn 1920, while work for the 1921 English census began in 1919. The Polish census was delayed, though not for administrative reasons. In April 1920, Piłsudski initiated an offensive against the Soviet Ukraine. The Polish army took Kiev in May. Grossman did not sympathize with Poland's foreign policy, offering, according to Christina Stead, to donate to a fund for milk for babies when approached to buy war bonds. ${ }^{35} \mathrm{In}$ June, a Soviet counter offensive liberated Kiev, then the Ukraine and moved on to undisputedly Polish territory, approaching Warsaw, Torun and Lwów by early August (Carr 1977 pp. 167-169; a less disinterested but more detailed Polish account is Zamoyski 1981). Poles of military age were called up during the emergency. As a former artillery officer, Grossman was posted to the Torun Artillery School, where he received his GUS salary for August. More an indication of rapid inflation than his promotion, it amounted, with supplements, to 4029 Marks, compared to 1320 Marks the previous December. ${ }^{36}$ The town was threatened by G. D. Gai's Russian cavalry corps around 15 August. But the crisis was soon over. The Polish army started a successful thrust from the south on 16 August which outflanked the Russian forces concentrating on Warsaw and decisively defeated the Red Army. Hostilities ceased in October, but Grossman's renewed military responsibilities were abruptly terminated for another reason: he 'was relieved of his command for suspicious behavior and [was] thereafter under police surveillance'. While there was suspicion about him, there was, apparently, no proof. He later told Stead that he had assisted the Soviet forces; there was a railway 'engine within range of [the] Russians, no one could run it, he could [and] therefore ran it to the Russians' ${ }^{37}$ Even if this story is apocryphal, Grossman ran considerable risks by being involved with the KPRP. With the Polish offensive into the Ukraine, repression of the Communist Party increased. In many areas its organizations fell apart or ceased to function for a period.

During 1921 Grossman dealt with the Polish railways in two further, entirely different ways. One was the frustrating exercise of organizing for the transport of his family's belongings from Vienna $^{38}$. The other was more abstract. Still responsible for preparing the now delayed census, he wrote a report, published in the GUS's journal, on rail freight statistics. It assessed contemporary practices in other countries and how they could be applied, in an improved form, to Poland. Reliable statistics were essential for management of the railways, let alone if Poland was to profit from the potential for increased international transit traffic--as 'the deficit on the state railways, which swallowed up 20 per cent of the budget was ... a constant drain' on state finances (Polonsky 1972 p. 106). The procedures the railways used in collecting statistics were inadequate and the results primitive. In the solid tradition of promoting the imperial interests of one's own department of the public service, Grossman recommended that responsibility for the task should

35 Christina Stead notes Box 6 Folder 45 Stead Collection.

36 GUS p. 11.

37 Christina Stead notes, Box 2 Folder 7 and Box 6 Folder 45, Stead Collection. Stead mentions that Grossman was stationed in Thorn (Torun) and links this with the railway engine story, giving her account credibility as a report of a conversation with him.

38 GUS pp. 14-18, 22, 24. 
be transferred to the GUS. His report made specific recommendations about territorial divisions, categories of freight, staff needed and their productivity if they worked manually or with typewriters. A memorandum of instructions on forms and procedures to implement the reform was appended to the article (Grossman 1921).

Despite his involvement in major, ongoing projects, on June 301921 Grossman gave one month's notice of his resignation from the GUS. He later explained this in delicate terms, 'certain difficulties which arose from my conception of my scientific responsibilities as the leader of the Population Census led me to leave my position in order devote myself, henceforth, to research and teaching'. Carl Grünberg put the matter more bluntly. As Grossman 'was not prepared to accept the fudging ('Frisierung') of the census results in favor of the Polish majority and against the interests of national minorities he left his post at the Statistical Commission and devoted himself exclusively to research and teaching'. How could a veteran of the struggles against the national oppression of the Jewish working class in Galicia be expected to go along with similar maneuvers by the authorities in independent Poland $?^{39}$ Grossman's departure from GUS tallies with criticisms of the census results by non-Polish historians (Horak 1961 pp. 80-83; Farmer 1985 p. 37).

At the GUS, there seems to have been sympathy with Grossman's position. Following inquiries from the Deputy Minister for Labor in Poland and Professor Corrado Gini, an Italian consultant to the League of Nations, about Grossman's 1917 study of the wealth of the Kingdom of Poland, the GUS journal published a revised version of it in 1922. Gini used Grossman's results in his own calculations of the wealth of the whole territory of independent Poland (Grossman 1922b; Marcus 1983 p. 250). ${ }^{40}$ Three years later, the GUS published another article by Grossman. Over one hundred pages long, it amounted to a monograph on the 1808 and 1810 censes in the Duchy of Warsaw. Napoleon had created the Duchy, in 1807 after defeating Prussia, from most of the territories Prussia had gained in the second and third partitions of Poland. The study drew on Grossman's pre-War research experience and was based on extensive archival investigations in both Warsaw and Kraków. It made the main statistical results of these censes available to the public for the first time and also undertook a systematic and comparative analysis of the methodology which underpinned them (Grossman 1925). In outlining the demographic and economic structure of the Duchy, Grossman supplemented the censes with references to other literature. A scholarly tour de force, Grossman's study is an important source for primary material on the economic history of Poland in the early $19^{\text {th }}$ Century ${ }^{41}$ It was, however, his last work to focus on the history of public statistics or Polish economic history.

\section{B. A university post}

Grossman became active at the Free University of Poland (Wolna Wrzechnica Polska, WWP), in Warsaw, from 1921 and was appointed to a full professorship in economic policy there in 1922. The WWP was set up in 1918 on the basis of the Association for Scientific Courses. The Association had been established in 1906, during the '1905' Russian revolution, as the first

39 GUS p. 21; Grossmann Curriculum vitae UFM p. 198; Carl Grünberg 'Gutachtlicher Bericht' UFM. Christina Stead noted that Grossman was dismissed from his position in charge of the census 'by new reactionary anti-semitic govt. insisted upon by French clericalism under Gen. Wigand commander at Warsaw and also by Papal Nuncio Achille Ratti later Pius XI', Box 6 Folder 45, Stead Collection. As General Weygand, the French military advisor during the Soviet-Polish War, had left Warsaw as early as 25 August 1920, Ratti was in Rome by 13 June 1921 and Wincenty Witos held office as Prime Minister at the head of an all party Government from July 1920 to September 1921, the details of this story are clearly mistaken.

40 Gini developed the Gini Coefficient which is a widely used measure of dispersal and hence, in a social context, of inequality.

41 For the use of this resource in a discussion of the Jewish population of Poland, for example, see Eisenbach (1972 p. 154). 
university level body in Russian Poland offering courses in Polish since the Tsarist crack down on Polish educational institutions after the 1863 uprising. The WWP continued this tradition and it quickly expanded its offerings to include the social sciences (Skubała-Tokarska 1967 pp. 247249). Five new chairs in the Faculty of Political and Social Sciences, including Grossman's, were created in 1921-22. The WWP's programs in political economy, sociology, education and psychology were superior to the those in the state universities. It therefore played a major role in the further education of professionals, especially teachers, and developed close relations with professional institutions. In 1921-22, there were 1499 students formally enrolled and a further 875 attending classes (Zagorowski 1924 p. 108). ${ }^{42}$

Like the GUS, the WWP was a haven for leftists and veterans of the Polish socialist movement. But here they could also express their views in their work. Amongst Grossman's colleagues was Zofja Daszynska-Golińska and later the anthropologist Władisław Gumplowicz. Members of the previous generation of PPSD intellectuals, Grossman had collaborated with both when he was a student during the first years of the century (Frančić 1962 pp. 81, 85; Przedswit 1904 p. 472; Myslinski 1967 p. 90; Buszko 1962 p. 235). Daszynska-Golińska had made a reputation for her social research, including a study of the Galician working class. Gumplowicz was a PPSD candidate in the 1907 Reichsrat elections (Piaseki 1982 p. 173). Adam Pragier, the professor of finance, was a leading figure in the PPS. Professor of sociology, Ludwik Krzywicki, had been one of the first popularizers of Marxism in Poland, as early as the 1880s. Adam Ettinger, who became the professor of criminology and retained his links with the radical left, had been delegated by the Bund to help rebuild Polish social democracy in the late 1890s, after it had been broken up by arrests (Strobel 1974 pp. 63, 124, 468). In addition to a post at the GUS, Stefan Szulc taught at the WWP (Tołwiński 1971 p. 172). Zygmunt Heryng, appointed to lecture in the Faculty of Political and Social Sciences while Grossman was there, worked with him at the Communist-influenced People's University. The WWP had another advantage; one of its campuses was conveniently situated at ul. Żórawia 49, down the street from Grossman's home.

The teaching load at the WWP was not high, three to six hours a week. Grossman's core course was on trade policy. In addition, he offered occasional courses on economic statistics, the struggle for international markets and the economic history of western Europe. To coincide with the $40^{\text {th }}$ anniversary of Marx's death, he taught 'The economic system of Karl Marx and its position in economic theory (during the 40 years since his death)' in the winter semester of 192223. One participant, Stanisław Tołwiński, remembered that Grossman 'presented the theory of Marxism in an intriguing way' (Tołwiński 1971 pp. 175-176). It seems Grossman had the confidence of most of his colleagues, not just the Marxist minority, as he was the secretary of the Faculty of Political and Social Science in 1924/25 (WWP 1924 p. 9). Respect for his professional competence found expression outside the WWP too. An active participant in the discussions of the Warsaw Association of Economists and Statisticians, and a presenter of papers at its meetings, he was elected to the society's Central Council in 1924. ${ }^{43}$ Through the Association, Roman Jabłonowski, a member of the Warsaw Committee of the KPRP, and Grossman became friends and made family visits to each other's homes (Jabłonowski 1962 pp. 243-244. Jabłonowski was a member of the KPRP Central Committee from April 1922 to early 1925 (Swietlikowa 1969 p. 141).

\section{Political reengagement}

The KPRP, established through the fusion, on 16 December 1919, of the SDKPiL and PPS (Left), was never a legally registered organization, but engaged in open activity through a number of 
political, cultural and union front organizations and publications while maintaining an underground apparatus. As we have seen, solidarity with or membership of the Party was risky in independent Poland. It was hardly a sensible course for anyone exclusively concerned with a successful conventional career or bourgeois public opinion. But the Russian revolution had dramatically reshaped leftwing politics in Europe and influenced Grossman's own views, opening up possibilities for political activity which the dominance of revisionism had closed in Galicia and Vienna before the War. So, while he very successfully resumed the career cut off in Vienna, he did not put this ahead of political commitment. When he joined the Communist movement in Warsaw he was at least as aware of the dangers involved as he had been when he took up socialist organizing in Galicia two decades earlier.

Grossman had been sympathetic to and cooperated with the SDKPiL before the War. Other former Bundists joined the Communist movement as individuals or with their organizations. In 1921, a faction led by Aleksander Minc and Abe Flug took the decision of the first Party Congress to affiliate with the Third International to its logical conclusion by joining the KPRP. When the second Bund Congress, in December 1921, adopted an anti-Communist line, the supporters of the Third International set up the Kombund, which entered the KPRP in 1923. Nor were members of the JSDP exempt from this process: 'The latter half of 1918 saw the emergence of small and scattered Communist groups in Eastern Galicia. In Drohobych, Boryslaw and Stryi, the members, especially in the latter two cities, were drawn in part from the Jewish Social Democratic Party and Poalei Zion' (Radziejowski 1983 p. 8; Dziewanowski 1976 p. 98; Schatz 1991 p. 95; Simoncini 1993 pp. 38-39, 84-86, 98).

Although Grossman was a member of the Party from 1920 to 1925 (Migdal 1981 p. 98), ${ }^{44}$ there is no evidence of his position in the factional debates which racked the organization during the 1920s nor that he played a significant role inside it. His activity in several front organizations, however, was prominent and important. Grossman was again an active organic intellectual of the working class.

In 1921-22, the Communist Party was experiencing healthy growth, after the setback of the Soviet-Polish War. Given that the Party was subject to persecution by the police, legal cultural and educational organizations were particularly important for the KPRP. They could openly bring together a range of militants under Party auspices--workers from different sectors, students, intellectuals, peasants--in a way that trade unions, for example, could not.

The largest organization of this kind was the People's University. Set up in 1915, Communists and PPS members were involved in the institution after the War but, in the course of 1921, paralleling the advances the Party made in the union movement, Communist influence became predominant (Cimek and Lucjan 1984 p. 47). The People's University offered popular and specialist courses and collaborated with the trade unions' Workers' School, a Communist initiative which offered a three-year academic secondary school (gymnazijalnego) program which covered history, economics, literature, arithmetic and geography (Kołodziej 1978 p. 154). Its facilities were also available to other educational and cultural organizations close to the KPRP, like the Workers' Culture (Kultura Robotnicza) association and the Book (Ksiażka) publishing cooperative.

At the start of 1922, the University's Chairperson was Ester Golde-Strozecka; Deputy Chairperson, Zygmunt Heryng; and secretary, Henryk Grossman. Later Grossman took over the chair. The Marxist philosopher Stefan Rudniański was on its governing board. The scale of the operation was substantial, it had its own premises including a cinema, conducted about 40 lectures a month, attended by 50 to 300 people and had programs of talks for trade unions. The 
lecturers included staff of the WWP, like Grossman, Ettinger and Zygmunt Heryng, high school teachers, Rudniański and Jerzy Heryng, Zygmunt's son (Meglicka 1968 p. 278). In 1919 Jerzy returned from emigration in Turin, the centre of the revolutionary movement in Italy, and assumed a series of increasingly responsible posts in the KPRP. In September 1920, he became a member of the KPRP's Warsaw Committee. In 1921 he joined the Cultural-Educational Department and then the Central Editorial Group of the Party's Central Committee. For a time, Jerzy Heryng was on the People's University payroll. So was Bołesław Bierut, as its bookkeeper. He was then a Party activist in his late 20s, in 1948 he became Communist Poland's Stalinist chief (Loth 1965 pp. 96-97). ${ }^{45}$

Grossman was widely respected in Communist circles. There were few intellectuals, still less professors who not only identified themselves as Marxists but also suffered political persecution for assisting the KPRP. So Grossman had a significant influence on radical students at the WWP. Jabłonowski recalled that in a leftist theatrical sketch Grossman was called 'one of the three "wise men" (Rudniański, Ettinger, Grossman), about whom it was sung: "Each one of us is famous for his wisdom, which of us is the wisest?"' (Jabłonowski 1962 p. 243)

Grossman made a triple contribution to the celebration of the $40^{\text {th }}$ anniversary of Marx's death in March 1923. The first was his course on Marxist economics at the WWP. Then Book, which was in practice the Communist Party's legal publishing house, issued the first Polish edition of Marx's Critique of the Gotha Program and letters to Kugelman, translated and introduced by Grossman. The Critique was an important intellectual weapon in the struggle against opportunism in the labour movement. Grossman pointed this out, but the bulk of his introduction was devoted to an outline of the earliest reception of Marxism in Poland from the 1870s, notably by Father Stefan Pawlicki, a professor at the Jagiellonian University (Grossman 1923a). For a while, Grossman also participated in a team translating Marx’s Capital for a Książka edition, which appeared in 1926 (Dolindowska 1977 p. 32).

Workers' Culture, a legal journal controlled by the Communist Party and published by the association of the same name, published a short article by Grossman, 'The economic system of Karl Marx', his third contribution to the Marx anniversary. Like the introduction to The critique of the Gotha Program, this piece began with the bourgeois reception of Marx. It provided a good description of the degeneration of mainstream economics from its achievements in the early $19^{\text {th }}$ century to the 'neoclassical' approach which still dominates the discipline today:

Ricardo's value theory laid a logical basis for the recognition of the bourgeoisie and proletariat as antagonistic classes. Bourgeois science, fearing the consequences of its own assumptions, retreated into the realms of history and ethics. Instead of studying the interdependence of phenomena in terms of economic laws, it limited itself to the description of economic relations through the ages. It also attempted to escape the ethical implications of class by offering ethical postulates, and reformist recommendations aimed at overcoming capitalism's shortcomings, without removing the basis of the system. These were the social motivations and conditions which gave rise to the so-called historical and socio-political schools of economics. This amounted to the bankruptcy of economics as a field of study. Even the bourgeoisie, which repeatedly tried to renew and rebuild the theory, understood this. However, the fear of the practical consequences of a science which threatened to be a theoretical reflection of the real phenomena resulted in the imposition of a priori restrictions on these attempts. In this way, it was possible to build a system more subtle than that of the medieval schoolmen. Economic laws could even be constructed, so long as they were not the laws of the real world. Thus a new bourgeois theoretical school emerged. Having previously escaped into the realms of history and ethics, it now escaped into psychology. This led from the surface of economic facts into the sphere of individual, inner psychological life, describing objective and accessible facts in terms of invisible psychological facts, inaccessible to research. (Grossman 1923b p. 295)

45 Grossman also provided a brief description of the extent of the activities of the People's University, 'Lebenslauf' UL, pp. 64-66. 
But Grossman concentrated on how volume I of Capital was received and used by the workers' movement. The first stage of his account echoed Rosa Luxemburg's 1903 discussion of the relative stagnation of Marxist economics in the late $19^{\text {th }}$ century (Luxemburg 1903). Thus

The first volume of Capital enjoyed the greatest understanding and popularity. Its contents shaped the conception of the Marxian economic system, 'so called'. This is understandable. In the first volume of Capital, the working class found an explanation of 'the secret of capitalist production', i.e. that labour creates all the wealth which the bourgeoisie accumulates. At the same time it found an explanation of how the results of workers' labour, in the form of surplus value become the profit, rent and interest of all kinds of bourgeois, while the real producer, the worker, has to satisfy himself with a very modest and inadequate wage. In the first volume, the worker found a theoretical explanation of all aspects of every day life in the factory, i.e. the capitalists' tendency to increase the exploitation of workers, to make them produce more, by extending working hours, lowering pay and, at the same time, increasing the intensity of work by introducing machines... (Grossman $1923 \mathrm{~b}$ p. 297)

Only later did some of Marx's other insights become directly relevant to mass working class activity:

The development of capitalism in Western-European countries at that time, was not mature enough yet for the everyday struggle to be conducted with reference to the socialist goal. This is why the whole complex of issues concerning the transformation of capitalism into socialism remained lifeless, in spite of Marx's impressive formulations in the first volume of Capital. The genius of his thought was that it anticipated in theory the development of the world economy for the next few decades. (Grossman 1923b p. 297)

In an argument that indicated his Communist views, Grossman maintained that these insights were subsequently distorted because,

in the course of the everyday practical struggle, an elite labour bureaucracy and labour aristocracy, which accepted the capitalist system and did not see any reason to abolish it, emerged from the proletariat. So, in the theoretical battle, the elite of the proletariat's educated leaders agreed with the current system, and employed their talents to glorify it. In the second volume of Capital, Marx gives some consideration to the possibility of production and consumption within the capitalist system becoming permanently stable. Hilferding, Kautsky and O. Bauer rushed to answer: such equilibrium is not only possible, but the mechanisms of capitalism are such that they automatically tend to restore equilibrium in production if it is temporarily disrupted. (Grossman 1923b p. 298)

Their approach diminished Marxism 'to the level of pre-Marxist theory (i.e. J. B. Say, Bastiat and Carey)' (Grossman 1923b p. 298). Grossman's criticisms indicated that he regarded the topic of his 1919 paper, the theory of economic crises, as a central issue for revolutionary politics. There was a close link between Karl Renner's crude reformist political practice and sophisticated rationales for capitalism formulated by economic theorists like Hilferding and Bauer, who were apparently well to Renner's left politically. This amounted to a development of Lenin's explanation, in Imperialism, The Highest Stage of Capitalism, of the rise 'social chauvinism'.

Understood in this twisted way, Marx's theory could no longer, of course, explain reality. That is why theoretical opportunism, not understanding the economic laws of the capitalist system, follows in the footsteps of bourgeois economics and retreats into concepts of ethics and justice. The capitalist state, subservient to the ruling class, is to be the instrument for achieving 'social justice'. And superficial Rennerism is only a practical formulation of conclusions whose theoretical foundations were developed by Hilferding and O. Bauer.

The so-called 'historicism' of bourgeois economics describes the early forms of capitalism, when it arose from previous modes of production. This kind of economics looks only into the past. It never analysed the issue of the 'possible end' of the capitalist system. Such an idea was too frightening; it preferred to write paeans of praise to progress and the continuing perfection of capitalism. That is why Marxian economics is the only scientific theory, which predicted processes that are now under way, analysed them and formulated the laws of their historical development, the process of the breakdown and collapse of the capitalist system. The opportunist literary attempts to distort Marxist 
theory, still being undertaken, must always fail when confronted with reality. (Grossman 1923b p. 298-299)

While on the staff of the WWP, Grossman also published two substantial academic works in the history of economic ideas and economic history in 1924 and 1925. One was his study of the Napoleonic Duchy of Warsaw (Grossman 1925), discussed above. The other was a Marxist analysis of Simonde de Sismondi's economic thought.

\section{On Sismondi}

In December 1923, Grossman had used another anniversary to explore the origins of theories of economic crisis in the history of political economy. He lectured on Simonde de Sismondi and his economic theories to the Economists' Society a little late, as Sismondi was born on 9 May 1773. The paper was published in French the following year as a 77 page monograph in the Free University Library series (Grossman 1924).

There is a continuity between Grossman's contributions to the Marx anniversary in early 1923 and his work on Sismondi. Both touched on the questions of Marx's methodology and theory of capitalist crisis. But where the earlier essays looked at the reception of Marx, the Sismondi study examined one of Marx's antecedents.

The Sismondi monograph deepened the considerable knowledge of the history of political economy Grossman had needed for his study of Austrian trade policy in Galicia and provided an overt critique of the most authoritative and widespread interpretation of Sismondi, by Charles Rist, in a standard reference work on the history of economic thought (Rist 1909). ${ }^{46}$ Grossman rejected Rist's contentions that Sismondi was a forerunner of the descriptive approach of the German Historical School; that his main contributions were his proposals for protecting workers rather than his economic theory; that an emphasis on the disproportional distribution of wealth differentiated him from the classical school of Smith and Ricardo; and that Marx's main debt to Sismondi lay in the description of the concentration of wealth and the proletarianization of wider layers of the population (Grossman 1924 pp. 2-3, 17, 39, 60). These arguments with Rist, of particular interest to an academic audience, were complemented by Grossman's comments on Rosa Luxemburg's extensive Marxist treatment of Sismondi in The Accumulation of Capital, which included references to Marx's own assessments of the Swiss economist. ${ }^{47}$

The first section of Grossman's study dealt with Sismondi's method. Contrary to Rist, the issue was not one of Sismondi counterposing an inductive approach to the abstract deductions of the classical school. Sismondi employed the method Grossman described in 1919: he considered whether equilibrium between production and consumption is possible in a country isolated from foreign trade.

It is only in a system thus isolated and simplified that Sismondi studies the relationships between supply and demand, having assumed a specific productivity of labour and determinate level of wages. Then multiplying one element, holding constant the productivity of labour while increasing wage by a defined per cent, he reexamines the influences of these changes on the relations of production and of consumption. (Grossman 1924 p. 10, also see p. 13)

46 The book went through multiple editions in French and also in English and German translations over the following forty years.

47 Grossman did not refer to Lenin's earlier, systematic critique of Sismondi as a forerunner of the Russian Populists. In a work with which Grossman was familiar, Luxemburg (1913, especially pp. 189, 287), had cited 'Ilyin's' study (Lenin 1897) in several places. My views on this point have been clarified in discussion with Paul Zarembka. When Grossman (1934) wrote a brief encyclopedia entry on Sismondi in 1934, he drew heavily on Lenin's criticisms. Following Lenin, as opposed to his own earlier position, he characterized Sismondi as an underconsumptionist. 
This was another step towards Grossman's better known discussions of Marx's method in the late 1920s (Grossman 1929a, 1929b).

Grossman's presentation of Sismondi's approach and critique of classical economics applies even more forcefully to the neoclassical economics that dominates the contemporary profession.

\begin{abstract}
Sismondi rejects this abstraction [of the classical school] not because it is abstract but because it is an abstraction which does not correspond with reality, because it does not take account of essential characteristics of the capitalist system. The simplification of reality should have its limits. 'The abstraction proposed ... is much too violent; it is not a simplification, it is a distortion which removes from our view all the operations ... in which we can distinguishes truth from error.'

... Sismondi is thus not opposed to abstraction in general, but solely to abstraction which leaves to one side the essential elements of reality. (Grossman 1924 p. 11)
\end{abstract}

In applying his method to the elaboration of the laws regulating the capitalist mechanism, Sismondi abstracted not only from foreign trade but also from survivals of precapitalist formations which are an aspect of empirical reality. 'Karl Marx adopted the same methodological foundations forty years later in his Capital'. There is an implicit rejection of Luxemburg's approach here. She recognized that Sismondi and Marx abstracted from foreign trade and precapitalist elements--and criticized them for doing so. Concretely, Sismondi's method took the form of an updated version of Quesnay's Tableau économique, replacing his productive, proprietorial and unproductive classes with capitalists and wage laborers. Contrary to Luxemburg's contention that before Marx only Quesnay undertook a rigorous study of the process of social reproduction, Grossman pointed out that Marx took over all of Sismondi's improvements (Grossman 1924 pp. 9-10, 13, 15; Luxemburg 1913 pp. 205, 348-351). ${ }^{48}$

Grossman's reference to Sismondi's use of 'thought experiments' also recalled his brief comments on the methodology of economics in 1919 and his comment on mathematical forms of presentation in economics is still telling,

The value of reasoning in modo geometrico, and hence the precision and accuracy of the results, depends not on the construction of formula but more on the construction of a specific method of research based on foundations clearly determined by and appropriate to the phenomena studied. Ricardo, despite all the artfulness of his method of thought lacks this method of research into the problem of general social reproduction and hence it is Sismondi who has the merit of having continued the methodological path indicated by Quesnay's Tableau, which later led to Marx's inspired methodological structure. (Grossman 1924 p. 16-17)

In the second section of his monograph, Grossman rejected the characterization shared by Rist, Luxemburg and others, that Sismondi was primarily an ethical purveyor of social reforms, concerned with the redistribution of wealth to workers. On the contrary, Simondi's most important contribution was to economic theory. He set himself the task of 'discovering the reasons why the actual course of events diverges from the fictitious harmonious course outlined by classical theory'(Grossman 1924 pp. 17-20, 25). At the center of his analysis was the distinction between use-value, the way commodities satisfy specific concrete needs, and exchange-value, the amount of abstract social labour embodied in commodities. Capital, he contended, is itself the most abstract form of exchange value. In a system based on exchange the goal of production is profit and the accumulation of abstract value, rather than the satisfaction of needs.

For society as a whole, real wealth remains solely the mass of useful goods and services which can satisfy needs. It is different for each individual producer. The capitalist is absolutely indifferent to the natural form of capital and the continuous real metamorphoses through which it passes in the course

48 Tadeusz Kowalik (1960), who reintroduced Grossman to a Polish audience in the 1960s, commented favourably on this aspect of his critique of Luxemburg. 
of labour. For him, the only important thing is the abstract value which he has invested in production and its expansion in the course of production itself and in circulation. (Grossman 1924 p. 28)

So Sismondi saw capitalism 'not as a system producing real goods for the satisfaction of needs but as the production and accumulation of abstract exchange value. And this why it is fair to regard Sismondi as the first economist who scientifically discovered capitalism' (Grossman 1924 p. 30). What is more,

\begin{abstract}
the economic theory of his time was nothing but a reflection of the contemporary economic organization based on abstract exchange value. If this organization is the source of lasting problems as a consequence of its defective construction, this fact also has repercussions for economic theory which rests on the same abstract basis of exchange value. The real contradiction of the economic system takes the form in science of incoherent and chaotic notions and definitions and pointless arguments about words ... 'It is the opposition between use value and exchange value ... which makes it impossible to offer a satisfactory definition of these various words: price, value, wealth.' (Grossman 1924 pp. 30-31)
\end{abstract}

As Grossman pointed out, this is 'the germ of the doctrine later developed by Marx, which he called economic fetishism, according to which the capitalist system has an objective tendency to obscure its real character, its institutions and the real source of its wealth' (Grossman 1924 p. 50). The resuscitation and application of this theory of fetishism, which Lukács called 'reification', was the source of some of the most powerful insights in the essays which made up Lukács' History and Class Consciousness, published in 1923. It is possible that Grossman, who later expressed admiration for this book was influenced by Lukács in highlighting the importance of the concept. Lukács's own treatment of Sismondi, however, was mainly critical and did not identify his insights into commodity fetishism (Lukács 1923 pp. 48-52, 64-66; Grossmann 1933 p. 316). ${ }^{49}$

For Sismondi, contradiction between use and exchange value meant that a disproportion between the scale of production and people's needs for specific commodities, as use values, arises. Because production is regulated by profit and not need, a part of the social product remains unsold and therefore does not contribute to the growth of wealth (in the form of use or exchange values). This insight was very similar to Grossman's crisis theory in his 1919 lecture, itself a version of disproportionality theory. It was possible because Sismondi corrected the individualist theory of Smith and Ricardo, according to which the value of a commodity is determined by the amount of labour involved in its production, with an addition of great significance, namely, that this must be labour necessary for production: "commercial value is always fixed, in the last analysis, by the quantity of labour necessary to procure the object evaluated." (Grossman 1924 pp. 33-38).

The determination of necessary labour and therefore the value of commodities cannot be predicted in advance. It is only apparent when the total number of commodities made by different producers confronts the need for them after they have been produced. As a consequence, disproportions can arise between what is produced and what is needed; hence economic crises occur, as commodities remain unsold. According to Grossman, then, the crucial issue for Sismondi was the disproportion between production and needs not, as Rist and Luxemburg had argued, a disproportion in the distribution of wealth between workers and employers. Sismondi's criticism of the classical economists went further. They argued that market forces will lead to an harmonious equilibrium, as production falls in response to the declining prices brought about by insufficient demand compared to supply. He suggested that many producers will increase production in the face of falling prices, as they try to maintain their incomes. So capitalism's problems were not passing episodes but a constitutive fault, 'a phenomenon that is renewed 
without cease, periodically and necessarily to the point that its regular repetition can be predicted.' (Grossman 1924 pp. 38-39, 42-45, 48-50)

Where, a decade earlier, Luxemburg (1913 pp. 217-218) had summarized Marx's judgements of Sismondi, Grossman now detailed the parallels between their approaches, notably in Capital, and the specifics of Marx's criticisms. Of greatest significance, Marx adopted a series of insights, pioneered by Sismondi, particularly that it was socially necessary labour which underpinned exchange value; that labour was the source of profit, rent and interest; and that the contradiction between use and exchange value gave rise to economic crises (Grossman $1924 \mathrm{pp}$. $27,38,44-45,52-53,56-57,59) .{ }^{50}$ Thus

\begin{abstract}
crises and overproduction, that is to say disproportional economic relations, are here [in Marx], as in Sismondi, not deduced from the unequal distribution of wealth or from the fact of the underconsumption of the working class but from the fundamental fact on which the entire edifice of the capitalist system is based: labour time is the measure of exchange value and as a consequence all relations of exchange are based on a variable standard, constantly changing, constantly being devalued. In effect, "every new invention", every machine perfected depreciates labour and thus the standard of exchange on which the capitalist system rests. That is why, once large scale industry systematically applies new inventions and new machines, disturbances are a necessary and constant phenomenon. Hence the critique Sismondi makes of machines. And after him, Marx: 'With the creation of large scale industry, this correct proportion had to come to an end, and thus production is compelled to pass in continuous succession through the vicissitudes of prosperity, depression, crises, stagnation, renewed prosperity, and so on.' (Grossman 1924 p. 58)
\end{abstract}

In political terms, according to Grossman, Sismondi implicitly advocated a minimum and a maximum program. His reform program was designed to improve the immediate situation of the working class, although he did not have any illusions in the state as a neutral institution. Grossman controversially characterized Sismondi as a socialist. Here, as with the issue of fetishism, Grossman may have drawn on Lukács (1923 p. 243), pointing out that Sismondi not only diagnosed capitalism's crisis tendencies but also saw the necessity of a superior system of production beyond capitalism in which free competition was superceded 'by an administrative system'. Unlike the utopian socialists, Sismondi grasped that conflict between the capitalist and working classes was inevitable. He also advocated both the abolition of abstract exchange value, the market and money and the transformation of capitalist production in the interests of the working class. But Sismondi did not recognize that the abolition of exchange value implied the abolition of private property, the usual standard for measuring socialist politics. Hence Marx's conclusion that Sismondi "forcefully criticizes the contradictions of bourgeois production, but he does not understand them"” (Grossman 1924 pp. 64-75). ${ }^{51}$

Grossman concluded that Sismondi grasped how the current economic system, based on abstract exchange value generates a fundamental contradiction which led to insoluble problems 'and it is on this point that Sismondi's doctrine constitutes one of the most important sources for the genesis of the scientific economic theory of Karl Marx (Grossman 1924 p. 77).

\title{
IV. To Frankfurt
}

The Sismondi and Duchy of Warsaw studies are impressive achievements, given the demands on Grossman's time. The issue was not so much his relatively modest teaching commitments as the costs of being in the hands of the Polish state. The political police's campaign against

50 It should be noted that Rist (1913 p. 211) pointed out that Marx 'might have discovered a trace of the surplus value theory in his [Sismondi's] writings'.

51 In the Communist Manifesto, Marx and Engels (1848 pp. 63-64) had earlier identified Sismondi as the head of the school of 'petty-bourgeois socialism', drawing a balance between the strength of this school's insights into the contradictions of capitalism and the weakness of its positive aims. 
Communism targeted Grossman amongst other Party members and sympathizers. From 1922 to 1925 he was arrested five times and held in custody for activities hostile to the state. 'My educational activity was increasingly persecuted,' he later wrote, 'searches were made at my institution, during which police agents also planted forged documents, and I was in police custody for two, four, even eight months.' Despite the fact that he was never convicted, during the period in custody, the shortest of which lasted eight days, he was suspended from his post at the WWP and received no income. ${ }^{52} \mathrm{He}$ was lucky compared to Stanisław Tołwiński, a radical student at the WWP, who Professor Grossman had helped get up to speed for a job at the GUS. The continuing anti-Communist repression soon included a government ban on the Workers' Culture organization and its publication; when 173 copies were found in his desk during a police raid on GUS in April 1923, Tołwiński's was arrested. Then, before his court case had concluded, the Minister for the Interior in the rightwing government that took office in late May sacked him. Although the ban on Workers' Culture was later lifted, Tołwiński was never reinstated (Tołwiński 1971 pp. 183-184). Kultura Robotnicza, however, was revived as New Culture (Nowa Kultura), with essentially the same staff, and was published by Book from 1 July (Loth 1965 p. 114).

As part of government efforts to close down all organizations close to the Communist Party, the police sealed the premises of the People's University on July 16 1924. In September, after individual issues had been repeatedly confiscated, Nowa Kultura was banned and the People's University was officially notified that it was being closed for anti-government activities (Loth 1965 p. 112; Meglicka 1968 p. 290). Then, on the evening of August 6, the political police raided an apartment, 9 ul. Królewska 31, in central Warsaw. It wasbeing used by the Secretariat of the Communist Party's Central Committee and was rented in Grossman's name. Four people were arrested on the spot and during the night ten more, amongst them 'big fish' in the Party (Gazeta 1924). Members of the Central Editorial Group of the Party including Jerzy Herying--the editor of Nowa Kultura--were also caught in the round up associated with the raid (Loth 1965 p. 97; Meglicka 1968 p. 290). Grossman was taken into custody and held the notorious Pawiak prison (Jabłonowski 1962 p. 243). ${ }^{53}$ There were almost 11000 arrests of suspected communists in Poland between 1919 and 1926. Arrest and imprisonment were important weapons used against the Party, despite the fact that a large proportion of those held, after the mid 1920s certainly a majority, were never convicted. Ławnik's conclusion about the scope of police harassment reflected Grossman's experience, 'Communists who avoided arrest were rather an exception and a majority of them were held in detention many times' (1978 pp. 38, 55-56).

This political persecution was the background to the breakdown of Henryk and Janina's marriage, though they were never divorced and apparently remained on good terms. There are two accounts of what happened, neither especially reliable. In 1967, Grossman's colleague in Frankfurt, Friedrich Pollock remembered that

Grossmann lived apart from his wife and son. I visited his wife in Warsaw in 1927 and came to know her as a gifted painter. The marriage seems to have broken down because Grossman's life was more and more exclusively occupied with his scientific work. ${ }^{54}$

The implication that Henryk's research meant he had no time for relationships cannot be taken seriously, in light of other limited but more reliable information about his private life. He did

52 'Lebenslauf' UL, pp. 64-66; Fragebogen March 15 1949, VdN-Akte von Henryk Großmann 13630, Kommunalabteilung für die 'Opfer des Faschismus', Rat der Stadt Leipzig, Sächsiges Staatsarchiv Leipzig (SSL).

53 Fragebogen, SSL. P. Minc (1954 p. 142), who had come over to the KPRP from the Bund also recalled the arrests in Summer 1925 but, it seems mistakenly, described Professor Grossman as a member of the Party's Central Editorial Group which used the apartment.

54 Letter from Friedrich Pollock to Klaus Hennings, July 13 1967, IV 10.1-94, p. 222, Max-Horkheimer-Archiv, Universitäts- und Stadtarchiv, Frankfurt am Main (MHA). 
produce publications of impressive quantity and quality, based on extensive studies in archives and specialist literatures. But the key issue in Janina's separation from Henryk seems to have been his political activity and, in particular, the time he spent in jail rather than on research. In semifictional notes based on Grossman, Christina Stead wrote that his wife left him as a result of family pressure while he was in prison. ${ }^{55}$

After Grossman's arrest in August 1924, there was a well publicised campaign for his release. This involved legal procedings and personal approaches to members of the government. Free of Communist connections, Janusz Buki made a valuable contribution to Grossman's legal defence after one of his arrests. Buki had experience in the public prosecutor's office, excellent establishment connections and decorations for his valour during the Soviet-Polish War.

Eventually, Jabłonowski recalled, 'Grossman was released on bail after prominent scholars intervened on his behalf before Prime Minister Władysław Grabski.' An unofficial arrangement with the Polish authorities for a kind of qualified exile seems to have been involved. He would leave the country but could visit for two weeks a year, so long as he only saw his family and did not engage in political activity. Grossman arrived in Frankfurt am Main from Warsaw on 4 November 1925 less than a fortnight before Grabski resigned. He immediately joined the Institute of Social Research, headed by his friend and academic mentor Carl Grünberg. ${ }^{56}$ Six months later, on 12 May 1926, Josef Piłsudski took power in Poland in a military coup.

Grossman did not join the German Communist Party. He was, however, a close sympathizer and remained a committed supporter of workers' struggles, as he had been for more than a quarter of a century. Generations of commentators have been almost willfully blind to his political views, insisting that he saw no role for working class activity (e.g. Bauer 1929, Braunthal 1929, Varga 1930, Hansen 1985 pp. 65, 142). But Grossman's writings in Frankfurt bore very clear marks of his experience as an active organic intellectual of the working class in Galicia and Warsaw. These publications also developed arguments formulated before he moved to Germany. The continuities in Grossman's outlook included his views on Marx's method, the importance of the distinction between use and exchange value, capitalism's necessarily crisis-prone nature and, most fundamentally, socialist revolution understood as a process of working class selfemancipation, involving 'an organization expressing the united will of the masses, with extensive experience in daily class struggles' (Grossman $1928 \mathrm{pp}$. 161-162)..$^{57}$

\section{ACKNOWLEDGMENTS}

I am grateful to Mary Gorman, Alex Gorman, Gerda Kuhn, Kurt Kuhn, Robert Kuhn, Michal Słiwa, Walentina Najdus, Julian Bugejski, Leo Greenbaum, Rakesh Bhandari, Jürgen Scheele, Stephan Toth and the late Bono Wiener all of whom provided encouragement and help in the research that lies behind this essay, as well as Dominika Balwin, Halina Zobel, Eugene Bajkowski and Floris Kalman who translated important material from Polish and Yiddish. Ron Geering, as Christina Stead's literary executor, very kindly gave me permission to examine her papers and discussed them with me. Kenneth Lapides provided valuable criticisms of and suggestions about a draft of this article. My research has been supported by funding from the Department of Political

55 Christina Stead notes, Box 6 folder 45 Stead Collection.

56 Chistina Stead notes, Box 6 Folder 45 Stead Collection. Information about Buki from Eugene Bajkowski, a friend of Buki's in Shanghai in 1948-1952, personal communication 29 February 2000. The date of Grossman's arrival in Frankfurt is from a Nazi state security organization, Arbeitsgemeinschaft zum Studium sowjet-russischer Planwirtschaft ('Arplan') 1942-43, IV A 1 b 4764/42 Berlin 30.12.42,

Reichssicherheitshauptamt R59 St 3/443 I, Bundesarchiv, Berlin (Bundesarchiv).

57 For a critique of the assertion, made by social democrats and Stalinists, that Grossman's approach amounted to an 'automatic' theory of capitalist breakdown, see Kuhn (1997). 
Science and the Faculty of Arts at the Australian National University and a small Australian Research Council grant. 


\section{References}

Abramovitch, Raphael, 1955. 'The Jewish Socialist Movement in Russia and Poland (1897-1919)' in Raphael R. Abramovitch et al., The Jewish people past and present volume II. Jewish Encyclopedic Handbooks, New York.

Anderson, Perry, 1976. Considerations on Western Marxism. New Left Books, London.

Bauer, Helene, 1929. 'Ein neuer Zusammenbruchstheoretiker'. Der Kampf, June 22 (6), pp. 270280.

Bauer, Otto, 1907. Die Nationalitätenfrage und die Sozialdemokratie. Verlag der Wiener Volksbuchhandlung Ignaz Brand, Wien.

---- 1913, 'The Accumulation of Capital', History of political economy. 18 (1), 1986, pp. 88110.

Braeuer, Walter, 1954. 'Henryk Grossmann als Nationalökonom'. Arbeit und Wirtschaft, 8(5), pp. 149-151.

---- 1966. 'Henryk Grossmann' in Historishe Kommission bei der Bayerischen Akademie der Wissenschaft (ed.), Neue Deutsche Biographie Band 7. Duncker \& Humblot, Berlin, p. 158.

Braunthal, Alfred, 1929. 'Der Zusammenbruch der Zusammenbruchstheorie'. Die Gesellschaft, 6, 2 (10), pp. 280-304

Bross, Jakob, 1924. 'Tsu der geshikhte fun der y. s. d. p. in galitsien', in Royte pinkes, tsveytes zamelband. Verlag Kultur Lige, Warszawa, pp. 22-48.

Bundesarchiv, Reichssicherheitshauptamt R59 St 3/443 I, Bundesarchiv, Berlin.

Bunzl, John, 1975. Klassenkampft in der Diaspora: Zur Geschichte der jüdischen Arbeiterbewegung. Europaverlag, Wien.

Buszko, Jozef, 1962. Ruch socjalistyczny w Krakówie 1890-1914: Na tle ruchu robotniczego w zachodniej Galicji. Wydawnictwo Literackie, Kraków.

1978. Zum Wandel der Gesellschaftsstructur in Galizien und der Bukowina. Österreichische Akademie der Wissenschaften, Phil. hist. Klasse, Sitzungsberichte Bd. 343, Wien, pp. 15-31.

Carr, E. H., 1977. The Bolshevik Revolution 1917-1923, Volume III. Penguin, Harmondsworth.

Carsten, F. L., 1986. The First Austrian Republic 1918-1938: a Study Based on British and Austrian Documents. Gower, Aldershot.

Cliff, Tony, 1975. Lenin, Volume 1: Building the Party. Pluto, London.

Cimek, Henryk and Lucjan Kieszczynski, 1984. Komunistyczna Partia Polski 1918-1938.

Książka i Wiedza,Warszawa.

Ćwikliński (ed.), Ludwig, 1917. Das Königreich Polen vor dem Kriege (1815-1914). Leipzig and Deuticke, Wien.

Dąbrowa, Marian, 1988. 'Die Kultur in Galizien 1867 bis 1914', in Walter Leitsch and Maria Wawrykowa, Polen Österreich: Aus der Geschichteiner Nachbarschaft. Österreichischer Bundesverlag and Wydawnictwa Szkolne i Pedagogiczne, Wien and Warszawa, pp. 220-238.

Dolindowska, Krystyna, 1977. 'Ksiqżka' $i$ 'Tom': Z dzijow legalnych widawnictw KPP 19181937. Centralne Archiwum KC PZPR, Warszawa. 
Dziewanowski, M. K., 1976. The Communist Party of Poland: An Outline History. Harvard University Press, Cambridge.

Dzierżyński, Feliks, 1931. 'Listy F. Dzierżyńskiego'. Z pola walki 11-12, pp. 109-112.

----- 1951. Pisma Wybrane. Książka i Wiedza, Warszawa, pp. 82-3.

Eisenbach, Artur, 1972. Kwestia rónounprawnienia Żydó w Królestwie Polskim. Książka i Wiedza, Warszawa.

Farmer, Kenneth C., 1985. 'National Minorities in Poland, 1919-1980' in Sephan M. Horak Eastern European National Minorities 1919-1980. Libraries Unlimited, Littleton, pp. 35-107.

Feyner, Leon, 1948. 'Di bundishe presse in Krake fun 1905 bis 1930', Historisher samlbuch: materialn un dockumentn tsushtayer tsu der geshichte fun algemayner yiddishn arbeter-bund. Farlag 'Ringen', Warszawa, pp. 18-23.

Frančić, Mirosław, 1962. 'Postępowe organizacje studenckie w Krakowie (1895-1914)', in Henryk Dobrowolski, Miroslaw Frančić and Stanisław Konarski (eds), Postępowe tradycje młodzieży akademickiej w Krakowie. Wydawnictwo Literackie, Kraków, pp. 59-131.

Gazeta Administracji i Policja Państwowej, 1924. 'Walka z komunizmem’ 9 August, pp. 679680.

Glicksman, Sigmund, 1920. 'Etapen biz zu der proklamirung fun der JSDP in Galitsye'. Sotsialdemokrat, May 1.

Glaser, Ernst, 1981. Im Umfeld des Austromarxismus: Ein Beitrag zur Geschichte des österreichischen Sozialismus. Europaverlag, Wien.

Gramsci, Antonio, 1971. Selections from the Prison Notebooks. New York, International Publishers.

Grandner, Margarete, 1995. 'Staatsbürger und Ausländer: Zum Umgang Österreichs mit den jüdischen Flüchtlingen nach 1918', in Gernot Heiss and Oliver Rathkolb (eds), Asylland Wider Willen, Flüchtlinge in Österreich im europäischen Kontext seit 1914. Verlag Jugend und Volk, Wien, pp. 60-85.

Grossman, Henryk, 1905. Proletariat wobec kwestii zydowskiej z powodu niedyskutowanej dyskusyi w "Krytyce”. Odbito w Drukani Wladyslawa Teodorczuka, Kraków, January.

----- 1907. Bundizm in Galitsien. Kraków, Ferlag der Sotsial-Demokrat.

---- 1911a. 'Rozleglosc Galicyi po zajeciu jej przez Austre'. Kwartalnik Historyczny, 25, pp. 472-478.

----- 1912. 'Polityka przemylowa i handlowa rzadu Terezynansko-Jozefinskiego w Galicyi 17721790'. (Till's) Przeglad prawa i administracyi, pp. 1-43.

---- 1920. 'Znaczemie i zadania pierwszego proszechnego ludnosci w Polsce'. Miesięcznik Statysticzny, 1, pp. 88-106.

---- 1921. 'Statystyka ruchu towaronego na kolejach zelaznych'. Miesięcznik Statysticzny, 3, pp. $1-28$.

---- 1922a. 'Teorja kryzysów gospodarczych (The Theory of Economic Crises)'. Bulletin international de l'académie Polonaise des sciences et des lettres. Classe de philologie, classe d'histoire et de philosophie. Les années 1919. 1920, (presented 16 June 1919), pp. 285-290.

----- 1922b. 'Majątek społeczny Królestwa Polskiego'. Miesięcznik Statysticzny 5, pp. 255-277. 
---- 1923a. 'Przycznek do historji socjalizmu w Polsce przed laty czterdziestu'. Karl Marx Karol Marks: Pisma niewydane, 1 Listy Marksa do Kugelmana, 2 Przyczynek do Krytyki socjaldemokratycznego programu partyjnego, Książka, Warszawa.

---- 1923b. 'Ekonomiczny system Karola Marksa'. Kultura Robotnicza 2 (10), number 32, 17 March, 295-299.

----- 1924. Simonde de Sismondi et ses théories économiques. Une nouvelle interprétation de sa pensée. Bibliotheca Universitatis Liberae Polniae, fasc. 11, Warszawa.

---- 1925. 'Struktura społeczna i gospodarcza Księstwa Warszawkiego na podstawie spisow ludnosci 1808-1810 roku'. Kwartalnik Statystyczny 2, pp. 1-108.

---- 1934. 'Sismondi, Jean Charles, Léonard Simonde de' in Edwin R. A. Seligman (ed.)

Encyclopaedia of the Social Sciences: Volume Fourteen, Macmillan, New York, pp. 69-71.

Grossmann, Henryk, 1911b. 'Eine Wiener Volkszählung im Jahre 1777'. Statistische Monatsschrift new series 16, pp. 56-58.

----- 1913 'Die amtliche Statistik des galizischen Aussenhandels 1772-1792'. Statistische Monatszeitschrift new series 18, pp. 222-233.

----- 1914. Österreichs Handelspolitik mit Bezug auf Galizien in der Reformperiode 1772-1790. Konegen, Wien.

---- 1916a. 'Die Anfänge und geschichtlich Entwicklung der amtlichen Statistik in Österreich'. in Statistische Monatsschrift new series 21, pp. 331-423.

----- 1916b. 'Erwiderung (zu einer Kritik von Alfred Gürtler)'. Statistichen Monatschrift new series 21, pp. 676-677.

----- 1917. 'Die Kreditorganisation des Königreiches Polen vor dem Kriege', in Ludwig Ćwikliński (ed.), Das Königreich Polen vor dem Kriege (1815-1914). Deuticke, Leipzig and Wien, pp. 180-209.

----1928. 'Eine neue Theorie über Imperialismus und die soziale Revolution'. Archiv für die Geschichte des Sozialismus und der Arbeiterbewegung, 13, 121-192.

-----1929a. Das Akkumulations- und Zusammenbruchsgetz des kapitalistischen Systems (zugleich eine Krisentheorie). Verlag Neue Kritik, Frankfurt am Main, 1970.

----- 1929b. 'Die Änderung des ursprunglichen Aufbauplans des Marxschen "Kapital” und ihre Ursachen'. Archiv für die Geschichte des Sozialismus und der Arbeiterbewegung 14, pp. 305338.

---- 1932a. 'Die Wert-Preis-Transformation bei Marx und das Krisenproblem'. Zeitschrift für Sozialforschung 1, pp. 55-84.

----- 1932b. 'Die Goldproduktion im Reproduktionsschema von Marx und Rosa Luxemburg', in Festschrift für Carl Grünberg zum 70. Geburtstag. Hirschfeld, Leipzig, pp. 152-184.

---- 1933, 'Die Fortentwicklung des Marxismus bis zur Gegenwart', in Henryk Grossmann and Carl Grünberg, Anarchismus, Bolschevismus, Sozialismus. Europäische Verlaganstalt, Frankfurt am Main, 1971.

---- 1992. The Law of Accumulation and Breakdown of the Capitalist System: Being also a Theory of Crises. Pluto Press, London.

Grossmann, Jindřich, 1906. 'Židovskă Strana Sociálnĕ Demokratickă v Haliči’, Akademie, Socialistickă Revue. German translation 'Die Jüdische Sozialdemokratische Partei in Galizien', in 
Raimund Löw, Der Zerfall der 'Kleinen Internationale', Nationalitätenkonflikte in der Arbeiterbewegung des alten Österreich (1889-1914). Europaverlag, Wien, 1984, pp. 220-227.

GUS, Akta Osobowe Henryka Grossmana, Centralna Biblioteka Statystyczna, Glowny Urzad Statystyczny.

Hass, Ludwik, 1992. 'Grossmann, Henryk', in Muzeum Historii Polskiego Ruchu Rewolucyjnego. Slownik Biograficzny Dzialaczy Polskiego Ruchu Robotniczego Tom 2, E-J. Ksiażka i Wiedza, Warszawa, pp. 384-386.

Hansen, F. R., 1985. The Breakdown of Capitalism: A History of the Idea in Western Marxism. Routledge and Kegan Paul, London.

Henke, Henke Nachlass, Archiv der sozialen Demokratie der Friedrich-Ebert-Stiftung, Bonn.

Hennings, K. H., 1970. 'Henryk Grossmann: Eine biographische Notiz' in Henryk Grossmann Das Akkumulations- und Zusammenbruchsgetz des kapitalistischen Systems (zugleich eine Krisentheorie. Second edition, Verlag Neue Kritik, Frankfurt am Main, pp. i-xi.

Heym, Stefan, 1995. Radek. Bertelsmann, München.

Hilferding, Rudolf, 1910. Finance capital: a study of the latest phase of capitlist development. Routledge \& Kegan Paul, London, 1981.

Horak, Stephan, 1961. Poland and her National Minorities, 1919-1939. Vantage, New York.

Howard, M. C. and J. E. King, 1989. A History of Marxian Economics, Volume 1 1883-1929. Macmillan, Basingstoke.

Howell, David, 1986. A lost Left: Three Studies in Socialism and Nationalism. Manchester University Press, Manchester.

Jacobs, Jack, 1992. On Socialists and 'the Jewish Question' after Marx. New York University Press, New York.

----- , 1998 'Written out of History: Bundists in Vienna and the Varieties of Jewish Experience in the Austrian First Republic'. In M. Brenner and D. Penslar (Eds), In Search of Jewish Communisty: Jewish Identities in Germany and Austria, 1918-1933. Indiana University Press, Bloomington and Indianapolis.

Jabłonowski, Roman, 1962. Wspomnienia (1905-1928). Panstwowe Wydawnictwo Naukowe, Warszawa.

Jacoby, Russell, 1975. 'The Politics of the Crisis Theory: towards the Critique of Automatic Marxism II'. Telos 23, Spring, p. 3-52.

Jay, Martin, 1973. The Dialectical Imagination: A History of the Frankfurt School and the Institute for Social Research, 1923-1950. Little Brown, Boston.

Jobst, Kerstin, 1996. Zwischen Nationalismus und Internationalismus: Die polnische und ukrainische Sozialdemokratie in Galizien von 1890 bis 1914. Ein Beitrag zur

Nationalitätenfrage im Habsburgerreich. Dölling und Galitz, Hamburg.

JSDP (Yidisher sotsial-demokratishe Partey/ Żydowska Partia Socjalno-Demokratyczna/Jüdische sozial-demokratische Partei), 1905a. 'Vos vilen mir?'. Yidishe sotsial-demokrat 2, May, Lemberg.

---- 1905b. Czego Chcemy?. Yidishe sotsial-demokratishe partey, Kraków.

---- 1905c. 'Odpowiedzi Polskiej Partyi Socjalno-Demokratycznej Galiciji’ in Jewish Social Democratic Party of Galicia Przed Kongresem, 2 June pp. 1-6. 
1905d. Bericht zum Gesamt-Parteitage der Oesterreichischen Sozialdemokratie in Wien 1905 (1 Mai-23 Oktober 1905). Der Sozial-demokrat, Kraków.

---- 1905e. An die Sozialdemokraten in Oesterreich. Kraków, Der Sozial-demokrat.

Kelles-Krauz, Kazimierz (Michał Lusnia), 1904. 'W kwestii narodowosci zydowskiej' in Kazimierz Kelles-Krauz Narod i historia: wybor pism. Panstwowy Instytut Wydawniczy, Warszawa, 1989, pp. 301-333.

Kisman, Yusf, 1966. 'Di yidishe sotsial-demokratishe bevegung in galitsie un bukovine', in G. Aronson et al. (eds), Di Geshikhte fun Bund 3. New York, Farlag Unser Tsait, pp. 337-480.

Kołodziej, Edward, 1978. Komunistyczna Partia Robotnicz Polski w Ruch Zawodowym 19181923. Książka i Wiedza, Warszawa.

Kowalik, Tadeusz, 1960. 'Henryk Grossman: polsko-niemiecki teoretyk ekonomii marksistowskiej'. Zycie gospodarcze 16, April 17, p. 2.

Kuhn, Rick, 1995. 'Capitalism's Collapse: Henryk Grossmann's Marxism'. Science and Society 59 (2), Summer, pp. 174-193.

---- 1997. 'Grossmann on Class Struggle, beyond Exegesis: a Response to Lapides'. Science \& Society 61 (2), Summer, pp. 236-243.

----- 1998a. 'Jewish Socialists in Galicia and Marxist Debates over the National Question before World War I', paper presented to the Political Thought and Capitalism Seminar, University of Newcastle (Australia), 17-19 February.

----- 1998b. 'Organizing Yiddish-speaking workers in pre-World War I Galicia: the Jewish Social Democratic Party', in Leonard Greenspoon (ed.), Yiddish language \& culture: then \& now. Creighton University Press, Omaha, pp. 37-63.

----- 2000, 'The Jewish Social Democratic Party of Galicia and the Bund', in: Jacobs, Jack (Ed.) Jewish Politics in Eastern Europe: The Bund at 100 Macmillan, London.

Lapides, Kenneth, 1994. 'Henryk Grossmann on Marx's wage theory and the "increasing misery" controversy'. History of Political Economy 26 (2), Summer, pp. 239-46.

Ławnik, Jozef, 1978. 'Represje policyjne wobec ruchu komunistycznego w Polsce 1918-1939'. Z pola walki, 83 (3), pp. 25-56.

Leksikon fun der nayer Yiddisher Literatur, 1958. Congress for Jewish culture, New York.

Lenin, Vladimir Ilych (V. Ilyin), 1897. 'A Characterisation of economic Romanticism', in V. I. Lenin Collected Works, Volume 2. Progress, Moscow, 1977.

Lenin, Vladimir Ilych ('N'), 1905. Two Tactics of Social-Democracy in the Democratic Revolution in V. I. Lenin Selected Works Volume 1. Progress Publishers, Moscow, 1977, pp. 425-427.

Leon, Abram, (1970) The Jewish Question: a Marxist Interpretation. Pathfinder, New York.

Loth, Roman, 1965. 'Kultura Robotnicza - Nowa Kultura 1922-1924: Szkice zdziejow prasy kulturalno-oswiatowej KPRP'. Przeglad Humanistyczny 1, pp. 93-115.

Löw, Raimund, 1984. Der Zerfall der 'Kleinen Internationale': Nationalitätenkronflikte in der Arbeiterbewegung indes alten Österreich. Europaverlag, Wien.

Lukács, Georg, 1923. History and Class Consciousness. Merlin, London, 1971. 
Luxemburg, Rosa, 1903. 'Stagnation and Progress of Marxism', in David Ryazanoff (ed.) Karl Marx: Man, Thinker and Revolutionist. Martin Lawrence, London, 1927, pp. 108-113.

---- 1913. The Accumulation of Capital. Routledge, London, 1963.

M. M. 'Bund' in C. Roth and G. Wigoder (eds), 1971. Encyclopaedia Judaica volume 4. Keter, Jerusalem, pp. 1498-1508.

Mahler, Raphael, 1952. 'The Economic Background of Jewish Emigration from Galicia to the United States' YIVO Annual of Jewish social Science. 7, pp. 255-267 .

Marcus, Joseph, 1983. Social and Political History of the Jews in Poland, 1919-1938. Berlin and Mouton, New York and Amsterdam.

Marx, Karl and Engels Friedrich, 1848. Manifesto of the Communist Party. Progress, Moscow, 1977.

Maurin-Bialostocka, Jolanta et al. (eds), 1975. 'Grossman, Janina' in Słownik Artystów Polskich i Obcych w Polsce Działajacych Malarze, Rzébiarze, Graficy: Tom II D-G. Polska Akademia Nauk. Instytut Sztuki, Zakład Narodowy imienia Ossolińskich-Wydownictwo, Wrocław, p. 485.

Meglicka, Maria, 1968. Prasa Komunistycznej Partii Robtniczej Polski 1918-1923. Zakład Historii Partii przy KC PZPR, Książkai Wiedza, Warszawa.

MHA, Max-Horkheimer-Archiv, Universitäts- und Stadtarchiv, Frankfurt am Main.

Migdal, Ulrike, 1981. Die Frühgeschichte des Frankfurter Instituts für Sozialforschung.

Frankfurt am Main, Campus Verlag.

Minc, P., 1954. Di geshikhte fun a falsher iluzye: zikhhroynes. Buenos Aires, Tsentral-farband fun poylishe yidn in argentina.

Molyneux, John, 1978. Marxism and the Party. London, Pluto.

Myśliński, Jerzy, 1967. Grupy Polityczne Królestwa Polskiego w Zachodniej Galicji (1895-1904. Książka i Wiedza, Warszawa.

Najdus, Walentyna, 1983. Polska Partia Socjalno-Demokratyczna Galicji i Slaska 1890-1919. Panstwowe Wydawnictwo Naukowe, Warszawa.

Piasecki, Henryk, 1978. 'Herman Diamand w latach 1890-1918'. Biuletyn Zydowskiego Instytutu Historycznego w Polsce 106 (2), April-June.

---- 1982. Sekcja Zydowska PPSD i Zydowska Partia Socjalno-Demokratyczna. Zaklad Narodowy im. Ossolinskich, Wrocław.

Pistiner, Jakob, 1915. review of Henryk Grossmann Österreichs Handelspolitik, in Der Kampf 8 (6), 1 June, p. 224.

Polonsky, Antony, 1972. Politics in Independent Poland 1921-1939: The Crisis of Constitutional Government. Oxford University Press, Oxford.

PPS, 'Sprawa Grossmana' sygn 305/V/11 podt. 3, Zespol akt PPS, Archiwum Akt Nowych, Warsaw.

Przedswit, 1904. 'Z ostatniego kongresu galicyjskiego'. 24 (10-12), October-December, pp. 464473.

Radziejowski, Janusz, 1983. The Communist Party of Western Ukraine 1919-1929. Canadian Insitute of Ukrainian Studies, Edmonton. 
Reiss, Anshel, 1973. Bereshit tenuot ha Poalim ha Yehudim be Galitsyah. World Federation of Polish Jews, Tel Aviv.

Renner, Karl (Springer, Rudolf), 1902. Der Kampf um der österreichischen Nation um den Staat. Deuticke, Leipzig.

Renner, Karl (Synopticus), 1899. Staat und Nation: Zur österreichischen Nationalitätenfrage. Deuticke, Wien.

Rist, Charles, 1909. 'Sismondi and the origins of the critical school', in Charles Gide and Charles Rist, A history of Economic Doctrines from the Time of the Physiocrats to the Present Day. Second edition, 1950, Harrap, London.

Rosdolsky, Roman, 1992. Untertan und Staat in Galizien: die Reformen unter Maria Theresia und Joseph II. Verlag Philipp von Zabern, Mainz.

Schatz, Jaff, 1991. The Generation: The Rise and Fall of the Jewish Communists of Poland. University of California Press, Berkeley.

Scheele, Jürgen, 1990. Der Beitrag Henryk Grossmanns zur Akkumulations- und Krisentheorie. Diplomarbeit im Fach Politikwissenschaft, Philipps-Universität, Marburg.

Simoncini, Gabriel, 1993. The Communist Party of Poland. Mellen Press, Lewiston.

Sobelman, Michael, 1990. 'Polish Socialism and Jewish Nationality: The Views of Kazimierz Kelles-Krauz'. Soviet Jewish Affairs, 20 (1), pp. 47-55.

Der Sotsial-Demokrat. 1905-1920.

SSL, VdN-Akte von Henryk Großmann 13630, Kommunalabteilung für die 'Opfer des

Faschismus', Rat der Stadt Leipzig, Sächsiges Staatsarchiv Leipzig, Leipzig.

Stead, Christina, 1986. 'The Azhdanov Tailors', in Christina Stead, The Ocean of Story. Penguin, Ringwood, pp. 115-125.

Stead Collection, Christina Stead Collection MS4967, National Library of Australia, Canberra.

Strasser, Josef, 1912. Der Arbeiter und die Nation. Junius Verlag, Wien, 1982.

Strobel, Georg W., 1974. Die Partei Rosa Luxemburgs, Lenin und die SPD: der polnische "europaische" Internationalismus in der russischen Sozialdemokratie. F.Steiner, Wiesbaden.

Skubała-Tokarska, Zofia, 1967. Społeczna Role Wolnej Wszechnicy Polskiej. Polska Akademia Nauk, Wrocław.

Swietlikowa, Franciszka, 1968. Kommunistyczna Partia Robotnicz Polski 1918-1923. Książka I Wiedza, Warszawa.

Swietlikowa, Franciszka, 1969. 'Centralne instancje partyjne KPP w latach 1918-1938'. Z pola walki 4.

Tobias, Henry J., 1972. The Jewish Bund in Russia from its Origins to 1905. Stanford University Press, Stanford.

Tobias, Henry J. and Charles Woodhouse, 1985. 'Revolutionary Optimism and the Practice of Revolution: The Jewish Bund in 1905'. Jewish Social Studies 47 (2), Spring, pp. 135-150.

Thon, Jakob, 1907. 'Die Berufsgliederung der Juden in Galizien'. Zeitschrift für Demographie und Statistik der Juden 3(8-9), August-September.

Tołwiński, Stanisław, 1971. Wspomnienia 1895-1939. Państwowe Wydnawnictwo Naukowe, Warszawa. 
Tuck, Jim, 1988. Engine of Mischief: An Analytical Biography of Karl Radek. Greenwood Press, New York.

Tyrowicz, Marian, 1964. 'Galizien unter österreichischen herrschaft. Die politischen und wirtschaftlichen Probleme in der neuesten polnischen Historiographie'. Österreichische Osthefte, 6.

UFM, Akten der WiSo Fakultät, Sig 45² Abt 150 Nr 376, Archiv der Johann Wolfgang Goethe Universität, Frankfurt am Main.

UL, 'Henryk Grossmann' PA 40, Universitätsarchiv Leipzig.

Varga, Eugen, 1930. 'Akkumulation und Zusammenbruch des Kapitalismus'. Unter dem Banner des Marxismus, 4 (1), pp. 60-95

Wiggershaus, Rolf, 1993. The Frankfurt School: Its History, Theories and Political Significance. Polity, Oxford.

Wistrich, Robert, 1981. 'Austrian Social Democracy and the Problem of Galician Jewry 18901914'. Year Book of the Leo Baeck Institute, Secker and Warbug, London, pp. 89-124.

Wróbel, Piotr, 1994. 'The Jews of Galicia under Austrian-Polish rule, 1869-1918'. Austrian History Yearbook 25.

WWP (Wolna Wszechnica Polska), 1924. Skład osobowy i spis wykładów: na rok akademicki 1924/1925. Warszawa.

Yago-Jung, Ilse, 1974. 'Einleitung', in Irving Fetscher (ed.), Marxisten gegen Antisemitismus. Hoffmann und Campe, Hamburg, 11-28.

Der yidisher sotsial-demokrat 1905.

YIVO, Bund Archive, YIVO Archive, New York.

Zagorowski, Zygmunt (ed.), 1924. Spis Nauczycieli: szkót wyższych, średnich,zawodowych, seminarjów nauczycielskich orz wykaz zakładow naukowych $i$ władz szkolnych. Lwów and Książnica Polska, Warszawa.

Zamoyski, Adam, 1981. The battle for the marchlands. East European Monographs and Columbia University Press, Boulder and New York. 